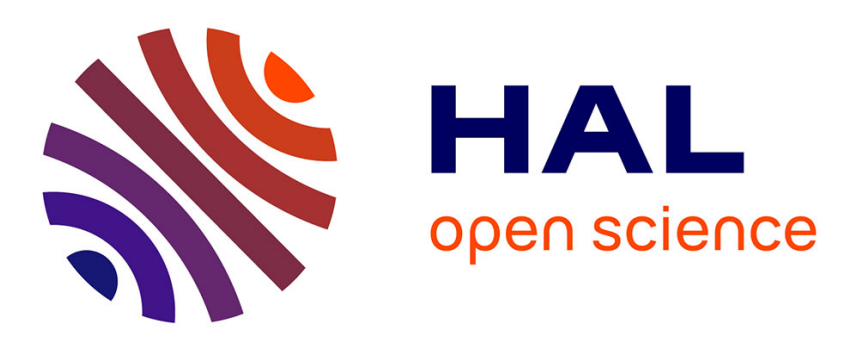

\title{
Translation: The Excavation of the Tomb of the Yang Gui Couple of the Tang Dynasty in a Southern Suburb of Xi'an
}

Annie Chan

\section{To cite this version:}

Annie Chan. Translation: The Excavation of the Tomb of the Yang Gui Couple of the Tang Dynasty in a Southern Suburb of Xi'an. 2018. hal-03221074

\section{HAL Id: hal-03221074 \\ https://hal.science/hal-03221074}

Submitted on 10 May 2021

HAL is a multi-disciplinary open access archive for the deposit and dissemination of scientific research documents, whether they are published or not. The documents may come from teaching and research institutions in France or abroad, or from public or private research centers.
L'archive ouverte pluridisciplinaire HAL, est destinée au dépôt et à la diffusion de documents scientifiques de niveau recherche, publiés ou non, émanant des établissements d'enseignement et de recherche français ou étrangers, des laboratoires publics ou privés. 


\section{The Excavation of the Tomb of the Yang Gui Couple of the Tang Dynasty in a Southern Suburb of Xi'an}

Shaanxi Provincial Institute of Archaeology 陕西省考古研究院

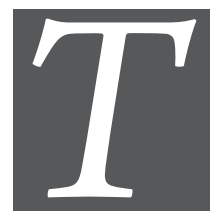

o facilitate capital constructions, the Shaanxi Provincial Institute of Archeology excavated a Tang dynasty tomb (No. 2013ZHCM7, hereinafter M7) in the period between September and December 2012. The tomb is located in Jinhutuo Village in Yanta District in the southern outskirts of

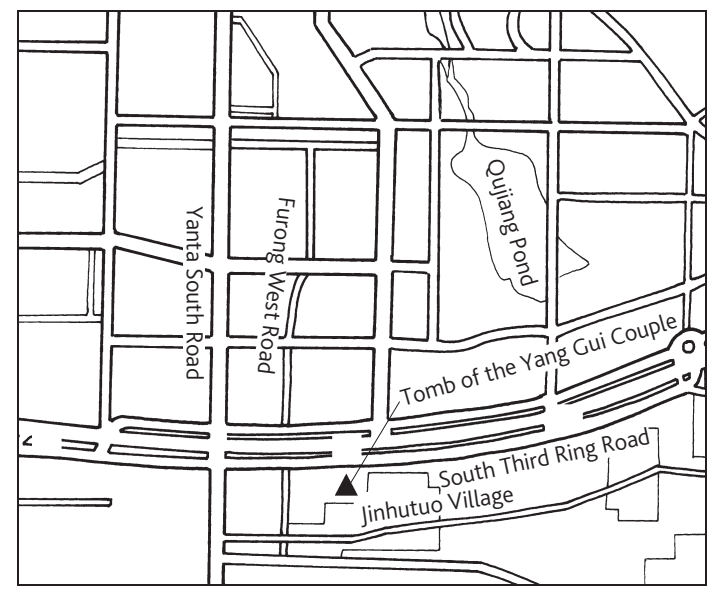

Figure 1: Location map of the tomb
Xi'an (now under the jurisdiction of Qujiang New District). It is south of the South Third Ring Road, east of the Furong West Road that is under construction, 2.2 kilometers south of the Tang dynasty site of Chang'an City (Figure 1). This place is located in the southeastern suburbs of Tang Chang'an City, formerly known as "Biyuan" or "Fengxiyuan." Many Tang dynasty tombs were found in the vicinity of the tomb, which include the tomb of the Li Shuang couple dated to the first year of the Tang dynasty (668 $\mathrm{CE})$, the tomb of Yao Wubi dated to the first year (697 CE) of the reign of Dowager Empress Wu. ${ }^{[1]}$ According to the epitaphs that were unearthed, this Tang dynasty tomb belongs to the Adjutant [Sima 司] 马] of Zizhou Prefecture, Yang Gui, and his wife. The results of the excavation are briefly described below.

\section{BURIAL STYLE}

This is a single-chamber earthen cave tomb with a long ramp access, furnished with ventilation shaft and niches. It has a south-facing knife-shaped 
plan. The entrance is located under the plow zone, $0.2 \mathrm{~m}$ beneath the surface. The tomb is composed of a ramp, guodong-passageways, ventilation shafts, niches, passages and the chamber. The entire length of the structure is $17.9 \mathrm{~m}$. The floor of the tomb is 6 meters beneath the surface with an orientation of $180^{\circ}$ (Figure 2).

Ramp: The earthen vertical pit has a sloped base. It has a rectangular plan view, with a small top and a large base. The walls of the chamber are lime, and paint is directly applied on top. A fuzzy image of a horse and horseman can be seen on the western wall. The slope extends to the entrance of the brick-sealed passage. It is $5.3 \mathrm{~m}$ long, $1.3 \mathrm{~m}$ wide at the southern end, and $1.24 \mathrm{~m}$ wide at the northern end. The slope is $5.56 \mathrm{~m}$ long with an inclination of 26 degrees; it measures $1.5 \mathrm{~m}$ at the base. The ramp is filled with mixed yellowish-brown deposit of unrammed earth.

Three guodong-passageways: These are earthen holes at the base of the slope. They have a rectangular plan view. There is a slight contraction at both ends, by $0.05-0.06 \mathrm{~m}$. The first crevice measures $1.1 \mathrm{~m}$ long north-south, $1.4-1.48 \mathrm{~m}$ wide, and $1.8 \mathrm{~m}$ high. The second hole measures $0.9 \mathrm{~m}$ long, $1.4-1.47 \mathrm{~m}$ wide, and $1.8 \mathrm{~m}$ high. The third hole measures $0.9 \mathrm{~m}$ long, 1.4-1.42 $\mathrm{m}$ wide, and $1.8 \mathrm{~m}$ high. There are traces of murals inside the guodong-passageways, but the design is not clear.

Three ventilation shafts: These are structures located at the base of the slope within the vertical shaft. They have a rectangular plan view, with a narrow top and a wide bottom. Neither the eastern nor the western wall is completely vertical; both the southern and the northern walls have a downward contraction. The first ventilation shaft measures $1.6 \mathrm{~m}$ long northsouth and $0.5 \mathrm{~m}$ wide; the base measures between $1.44 \mathrm{~m}$ and $1.48 \mathrm{~m}$ wide, and $3.3 \mathrm{~m}$ to $4.04 \mathrm{~m}$ deep. The second vault is $1.7 \mathrm{~m}$ long and $0.55 \mathrm{~m}$ wide; its base is 1.4-1.44 $\mathrm{m}$ wide and 4.44-5.2 $\mathrm{m}$ deep. The third vault is $1.6 \mathrm{~m}$ long and $0.5 \mathrm{~m}$ wide; its base is 1.4-1.44 $\mathrm{m}$ wide and 5.6-6 $\mathrm{m}$ deep. Traces of murals

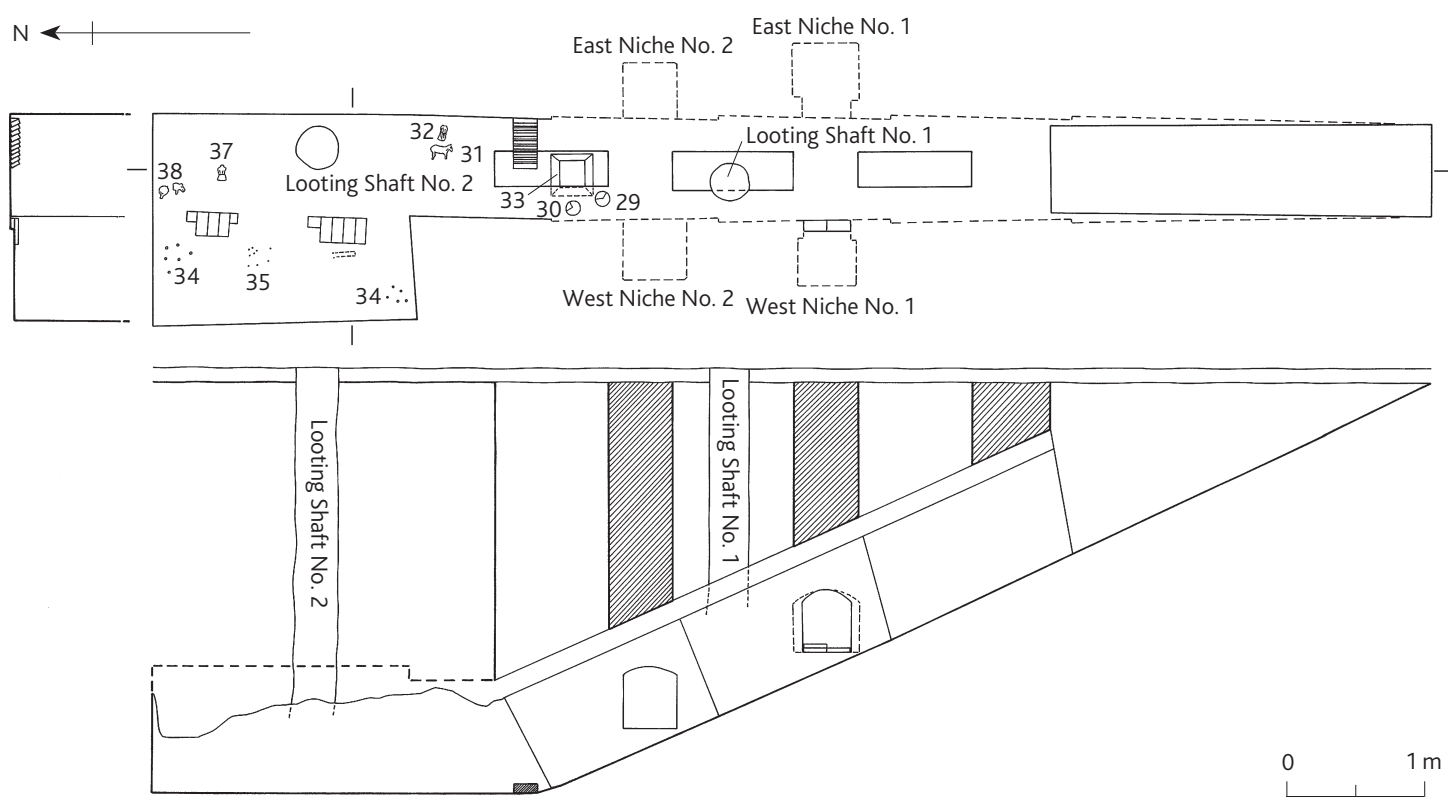

Figure 2: Plan view and profile of Tomb M7

29, 30. Pottery pen-basins 31. Tri-colored horse figurine 32 , 37. Tri-colored horse-riding figurines

$\checkmark$ 33. Epitaph $\$ 34$. Bronze coins 35 . Glass beads $\$ 36$. Tri-colored cow figurine 


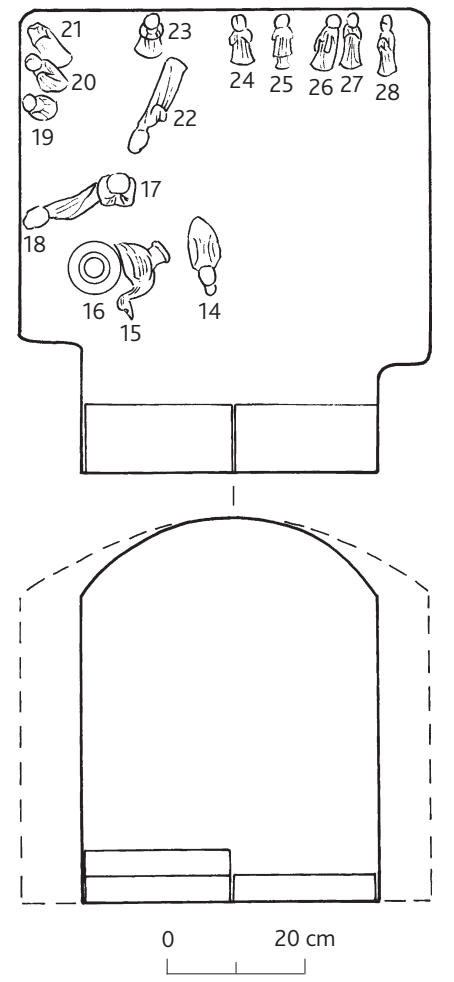

Figure 3: Plan view and profile of East Niche No. 1

14, 15. Tri-colored wild geese figurines $\diamond$ 16. Tricolored yu-water pot $\checkmark 17,18,21,24,26,27$. Tricolored maid figurines $\checkmark 19,20,22,23,25,28$. Tricolored male servant figurines
Figure 4: Plan view and profile of West Niche No. 1 1................................. 1. Tri-colored Hu figurine $\checkmark 2,3,4$. Tri-colored maid figurines $\diamond, 6,10,11$, 12. Tri-colored male servant figurines $\diamond$. Tri-colored pestle $\diamond$. Tri-colored latrine 9 . Tri-colored millstone 13. Tri-colored yu-water pot

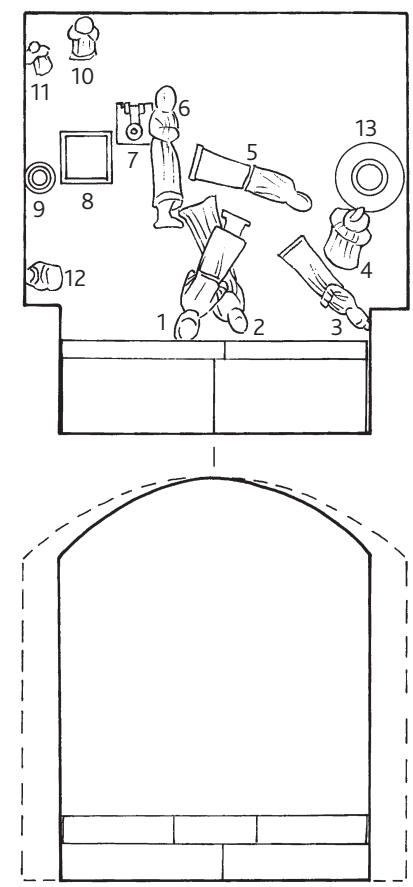

$0 \quad 20 \mathrm{~cm}$ are found at the bottom of the eastern and western walls of the vault, but they have largely peeled off and the designs cannot be identified. There is a looting shaft slightly west of the center of the second ventilation shaft, which opens out to the ground surface. It has a round plan view with a diameter of $0.53 \mathrm{~m}$; it connects directly to the ramp.

Four niches: These are crevices cut symmetrically into the east and west sides of the second and third guodong-passageways, two on each side. The entrances to the niches in the second passageway were closed off by alternating bricks and adobe. The bricks measure $0.34 \mathrm{~m}$ long, $0.16 \mathrm{~m}$ wide and $0.06 \mathrm{~m}$ thick. The adobe portion is $0.36 \mathrm{~m}$ long, $0.2 \mathrm{~m}$ wide and $0.08 \mathrm{~m}$ thick. The width of the eastern niche is $0.68 \mathrm{~m}$, the posterior width is $0.94 \mathrm{~m}$, the depth is $1.06 \mathrm{~m}$ and the height is $0.88 \mathrm{~m}$. Fifteen pieces of tricolored burial objects were placed inside the niche (Figures 3 and 5). The western niche is $0.68 \mathrm{~m}$ wide; the posterior width is $0.84 \mathrm{~m}$. It has a depth of $0.92 \mathrm{~m}$ and a height of $0.88 \mathrm{~m}$. Thirteen tri-colored burial objects are found inside the niche (Figures 4 and 6 ). The second pair of niches are found on either side of the third passageway. They both have a square plan view. The second eastern niche measures $0.76 \mathrm{~m}$ in width, $0.8 \mathrm{~m}$ in depth and $0.9 \mathrm{~m}$ high. The second western niche is $0.9 \mathrm{~m}$ wide, $0.86 \mathrm{~m}$ deep and $0.96 \mathrm{~m}$ high. These two niches have been completely looted. There is nothing inside except for silt deposits.

Passage: This is an earthen hole. It has a rectangular plan view that measures $2 \mathrm{~m}$ in length, 1.4-1.42 $\mathrm{m}$ in width and $1.8 \mathrm{~m}$ in height. The surface of the wall is uniform, with traces of murals. The ceiling is collapsed, and the interior is filled with sediments from the collapse and other events of disturbance, mixed with a small amount of brick slab fragments and ceramic sherds. The entrance of the passage is closed off by a brick door, of which only one layer of masonry 
remains as a result of looting. The placement of bricks in a running bond pattern is similar to how they are arranged in the niches.

Grave chamber: This is an earthen cave structure, rectangular in plan view, measuring 3.6-3.7 m long and 2.88-3 $\mathrm{m}$ wide. The walls are quite straight and originally had murals on them. The ceiling has collapsed, the remaining height is $1.6 \mathrm{~m}$. The earthen coffin bed is in the western part of the chamber, it is rectangular in profile and measures $3.6-3.7 \mathrm{~m}$ in length and $1.42-1.62 \mathrm{~m}$ in width. The bed is raised about $0.06 \mathrm{~m}$ above the chamber floor. The base of the exterior of the coffin bed is lined with brick slabs. Only two levels remain; bricks in the lower level are laid in one direction and bricks in the upper level are laid transversely. The chamber is filled with silt and sediments from the collapse, mixed with a small amount of brick fragments. There is a looting shaft of $0.6 \mathrm{~m}$ in diameter east of the center of the chamber. The opening is on the ground surface; it cuts through raw soil and connects directly to the chamber.

The tomb has been seriously looted; the intrusions were made recently. A number of rusty iron nails for a wooden coffin were found in the sedi-
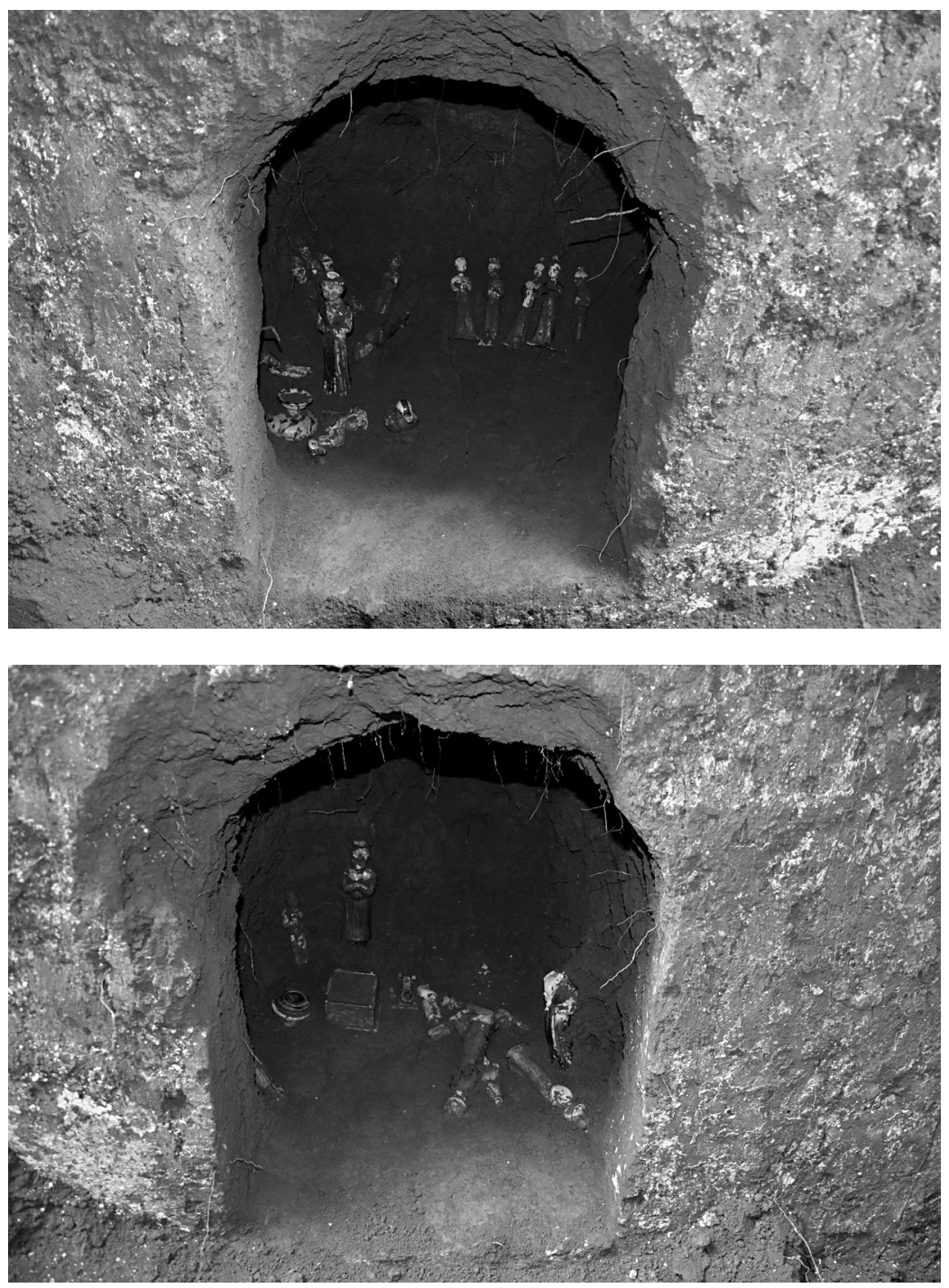

Figure 5: East Niche No. 1 .......................

Figure 6: West Niche No. 1 
ments. A small amount of bone residue was found on the earthen burial place; the type of burial is unclear.

\section{GRAVE GOODS}

Forty-five pieces (sets) of grave goods were unearthed from the tomb. They include tri-colored figurines, animals, models, containers, pottery wares, coins, a tombstone, etc.

\section{(A) Tri-colored Glazed Ware}

\section{Human Figurines}

Twenty-three pieces were discovered in the first eastern and western niches, the passage and the chamber. There are horse-riding figurines, maid figurines, male servant figurines and Hu image figurines. The head, face, neck and chest of the figurines are not glazed. The chignons are painted black, the faces are painted pink and the facial features are drawn.

Horse-riding figurines ( 2 items): They are both severely damaged, and reconstruction was not possible. M7:32 was found in the passage. The maid figurine dons a white narrow-sleeved shirt and a white half-sleeved coat. She is wrapped in blue silk and wears a long green dress. The saddle is blue. The remainder of the figurine measures $18 \mathrm{~cm}$ high. M7:37 comes from the chamber. The male figurine dons a brown robe with straight lapels and a round collar. The robe is tied at the waist. The collar folds outward, revealing a blue-green lining. The back is painted in a green glaze. The remaining height is $18 \mathrm{~cm}$.

Nine maid figurines were uncovered. They can be distinguished into three types based on their shape.

Type A ( 2 items): Tall build. The upper body features a narrow-sleeved shirt worn open-chested; the shoulders are covered by a silk shawl; and the hands are cupped together in front of the chest, wrapped inside the shawl. Around the lower body is a long skirt dragging on the ground, with round-toed shoes peeking out. The hair of M7:4 is combed into a high chignon; the figurine wears a white blouse, blue silk shawl, and a skirt with brown vertical stripes alternating with white dots on a blue background. The tips of the shoes are green. The figurine is $40.5 \mathrm{~cm}$ high (Figure 7:1; Figures 13 and 14). The hair of M7:17 is combed into a mallet-shaped bun; the figure wears a white blouse, green silk shawl, and a skirt with brown, blue, and white vertical stripes. It is $37.6 \mathrm{~cm}$ high (Figure 7:2; Figures 15 and 16).

Type B ( 3 items): The hair is combed into a mallet-shaped bun. A narrow-sleeved blouse is worn on the upper body; there is no shawl. The hands are folded in front of the chest, with the left hand on top of the right. A thin band is secured around the waist, with the straps dangling diagonally. Around the lower body is a dress dragging on the floor, with the toes hidden. M7:3 is wearing a white blouse and brown skirt, with a color gradient between the blouse and the skirt. The figurine measures $26.2 \mathrm{~cm}$ high (Figure 7:3; Figures 17 and 18). M7:24 is wearing a white blouse with a multicolored skirt of blue, white, brown and green. The figure measures $25.7 \mathrm{~m}$ high (Figure 7:4; Figures 19 and 20). M7:27 is wearing a blue blouse, with a color gradient transitioning to a brown skirt. The figure is coated in green glaze. It measures $25.7 \mathrm{~cm}$ high (Figure 7:5; Figures 21 and 22).

Type C (4 items): The hair is combed into a mallet-shaped bun. The upper body wears a narrowsleeved blouse with a half-sleeved jacket; the shoulders are covered with a silk shawl. The hands are cupped together in front of the chest, wrapped inside the silk shawl. Around the lower body is a long skirt dragging on the floor. M7:2 is wearing a blue shirt, white half-sleeved jacket, brown silk shawl and green skirt. The figure measures $27.2 \mathrm{~cm}$ high (Figure 8:1 and Figure 23). M7:18 has plump cheeks colored pink, thick brows, narrow eyes, a straight nose, and full lips painted vermillion. The figure wears a white shirt, with half the length of the sleeves painted brown with a green glaze; a blue silk shawl; and a 

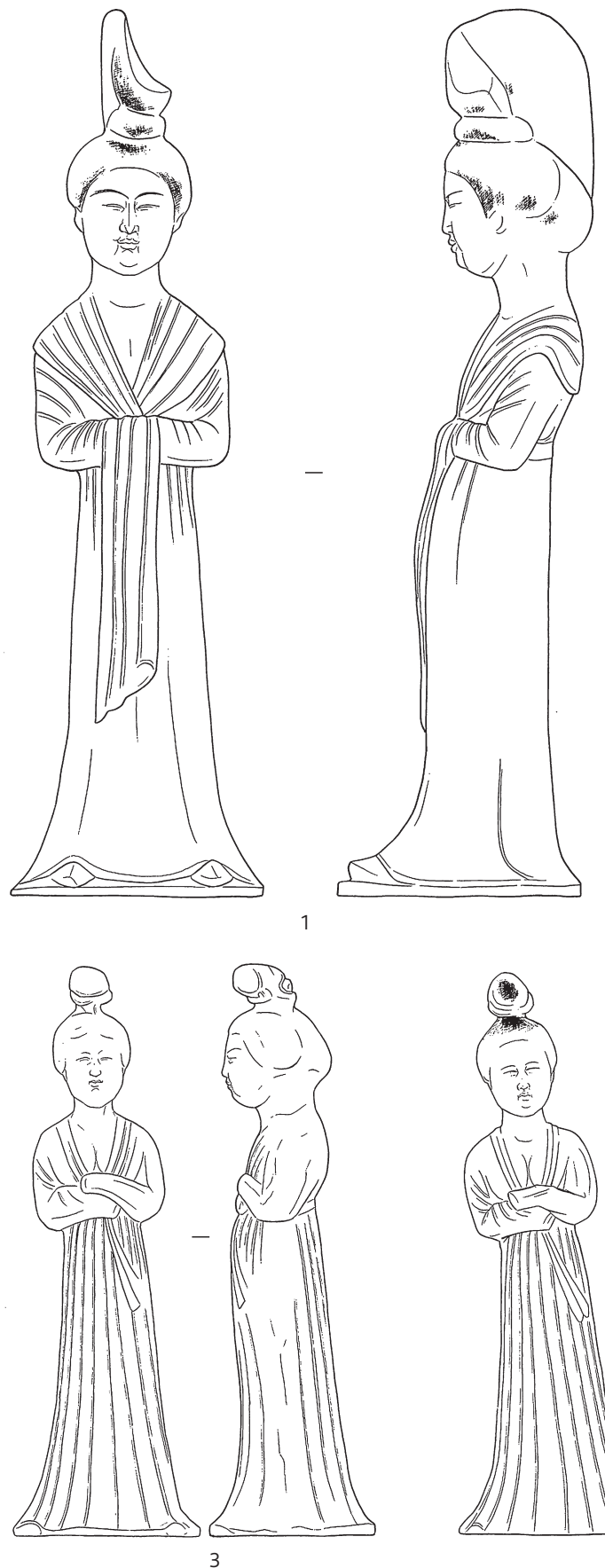

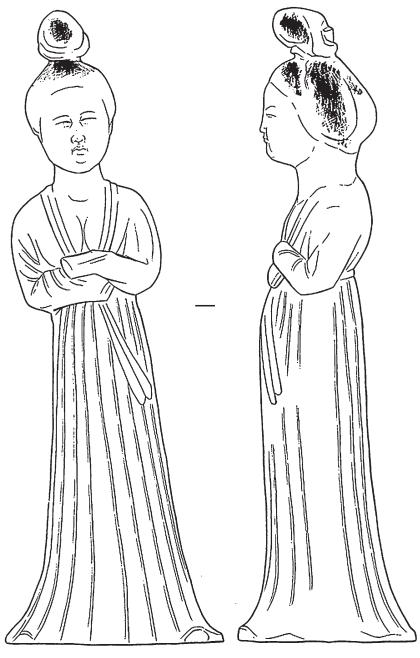

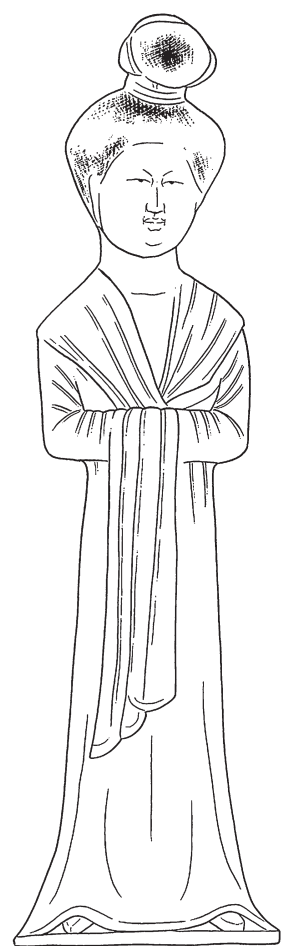

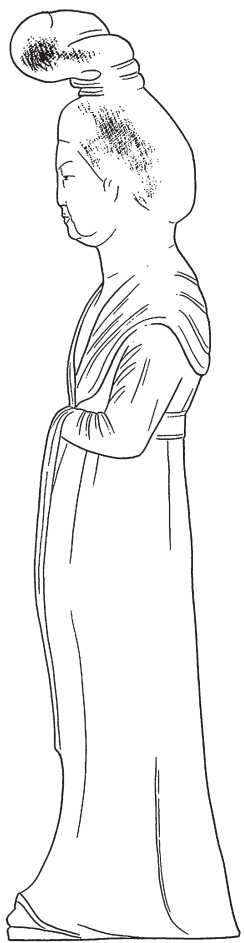

2

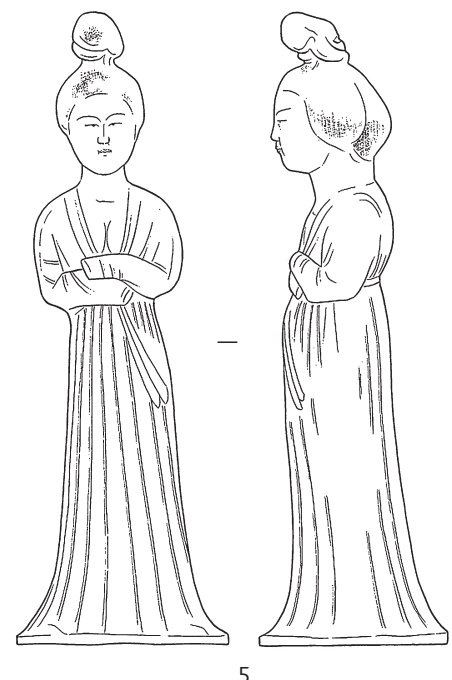

Figure 7: Tri-colored figurines

$\checkmark$ 1, 2. Type A maid figurines $(M 7: 4,17) \diamond 3,4,5$. Type B maid figurines $(M 7: 3,24,27)$ (all scaled 1:4)

brown, green and blue skirt with white dots. The height is $26.5 \mathrm{~cm}$ (Figure 8:2 and Figure 24). The lips of M7:21 are upturned into what looks like a smile; the top half of the arm is not clearly delineated. The figure wears a white shirt, half-sleeved jacket, brown silk shawl, and a skirt with blue and white spots. It is 
$27.9 \mathrm{~cm}$ high (Figure 8:3; Figures 25 and 26). M7:26 is wearing a green blouse, blue half-sleeved jacket, white silk shawl, and a skirt with brown, green, blue and white dots. It measures $27 \mathrm{~cm}$ high (Figure 8:4; Figures 27 and 28).

Eleven male servant figurines were uncovered. They all wear folded hats, their hands are cupped together in front of the chest, and they stand on rectan-
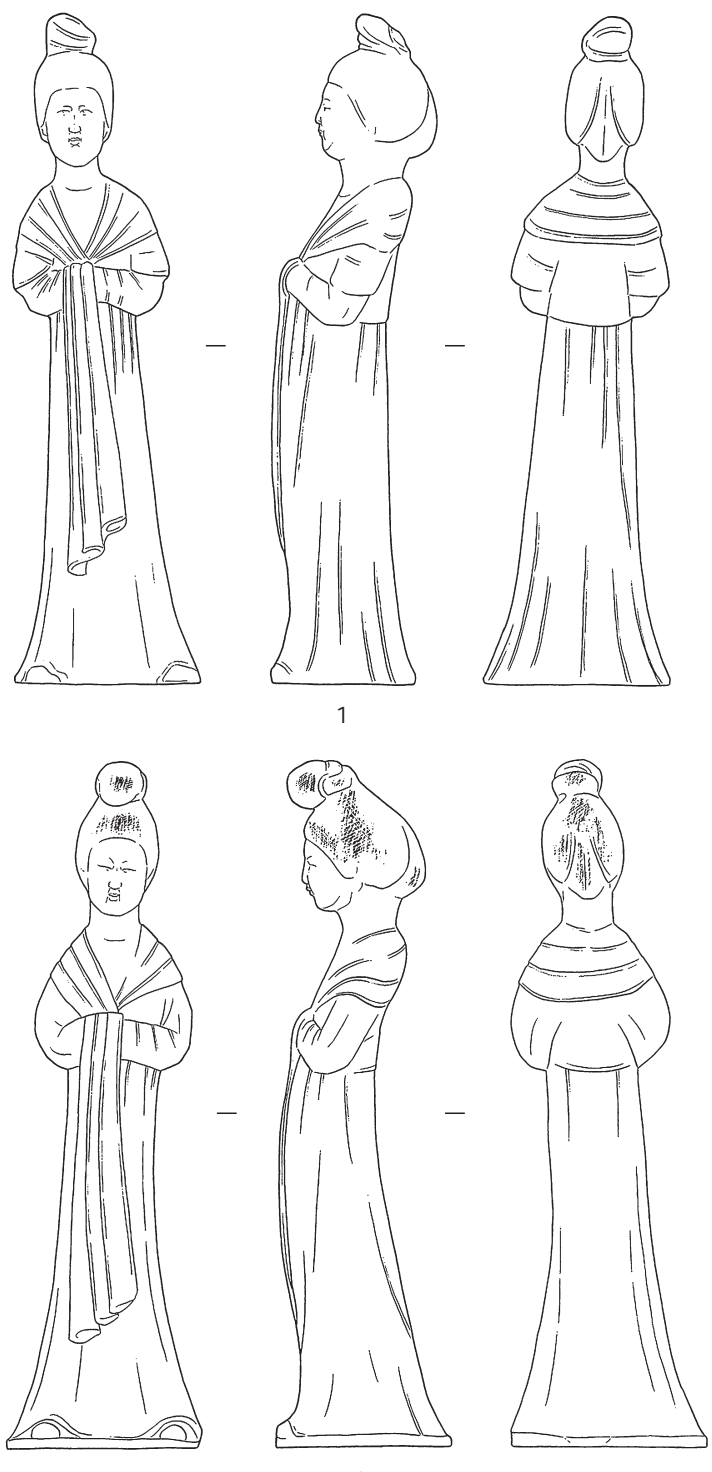

gular pedestals. These figurines can be distinguished into three types.

Type A (1 item: M7:10): Large build, small eyes, wide nose, curled lips, protruding cheekbones with a vivid expression. The hat is lined and folded into a two-part turban. The figurine wears a green robe with narrow sleeves, round collar and straight lapels. The robe falls below the knees. The collar is turned
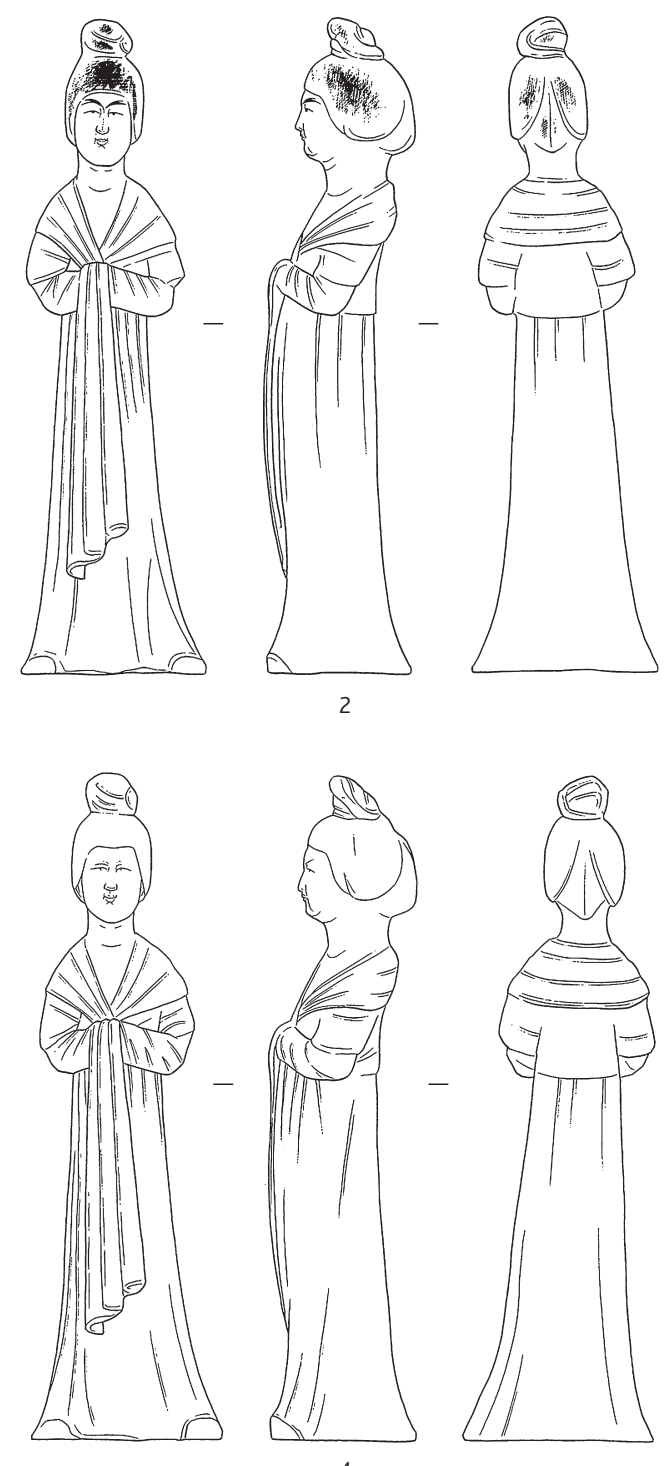

Figure 8: Type $C$ Tri-colored maid figurines 

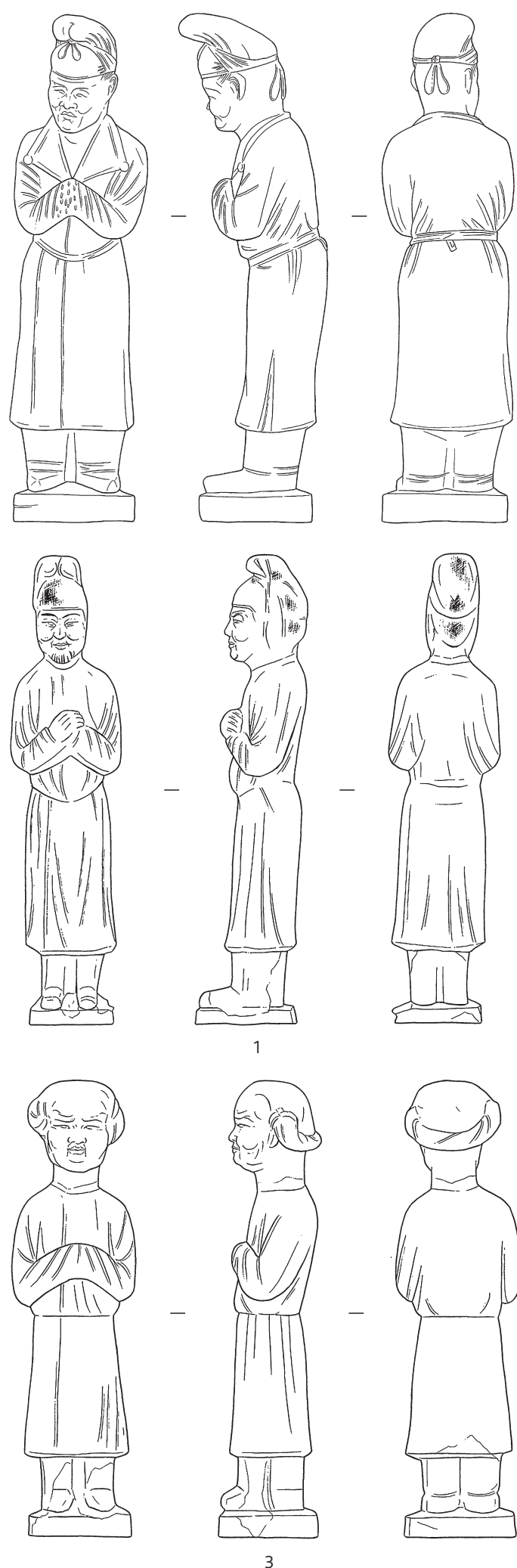

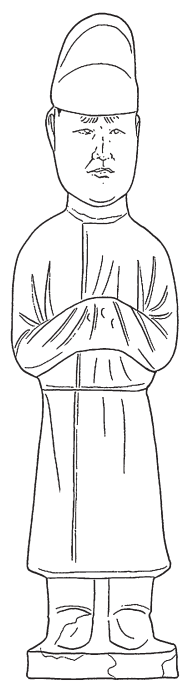

Figure 10: Tri-colored figurines

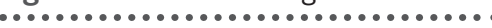

1. Type B male servant figurine $(M 7: 20)$ 2, 4. Type $C$ male servant figurine $(M 7: 22) \diamond 3$. Hu figurine $(M 7: 1)$

(all scaled 1:4)

Figure 9: Type A Tri-colored male

servant figurine (M7:10) (scale 1:5)
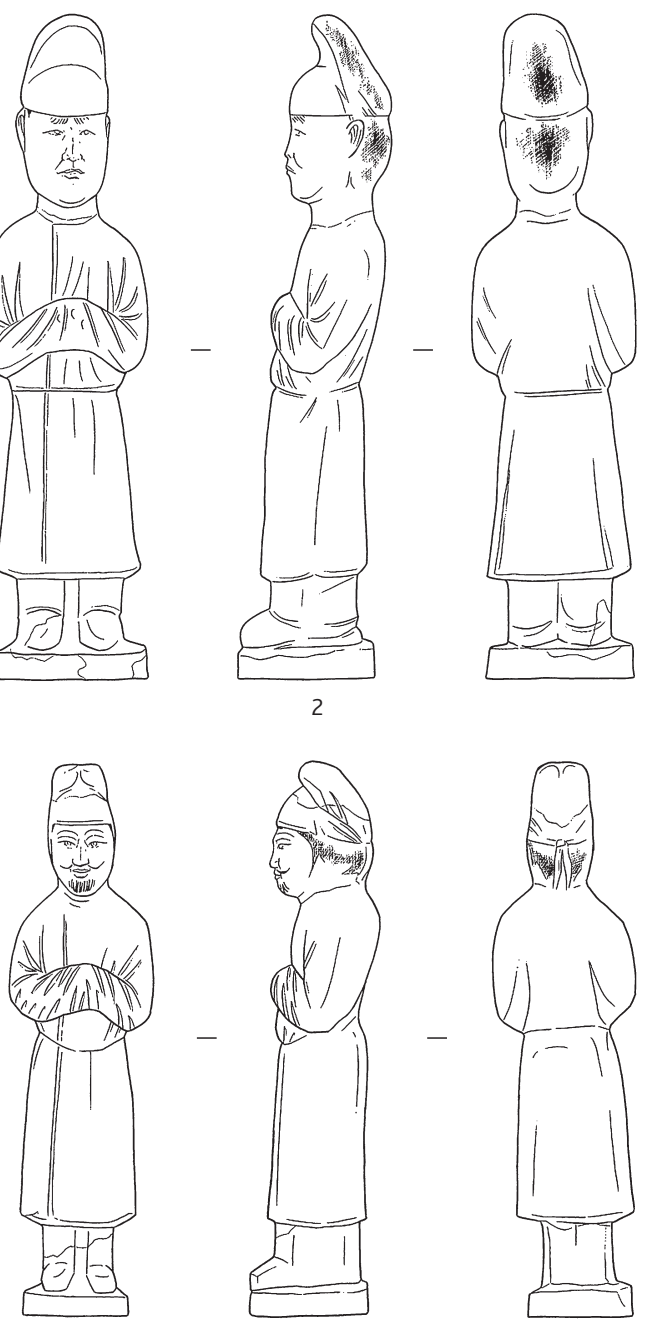
outward, exposing the brown lining. There is a tie at the waist. The figurine wears tall black pointed boots. The robe is glazed and the boots are painted in pastel. It measures $34.1 \mathrm{~cm}$ high (Figures 9, 29 and 30).

Type B (4 items): M7:20 has a pink face, and the lips are painted in vermilion. The eyebrows, eyes, mustache and the short beard beneath the chin are drawn in black. The hat is lined and folded into twopart turban. The figurine wears a brown robe with round collar, straight lapels and narrow sleeves. The robe falls below the knees; it is tied at the waist. Both hands are placed in front of the chest, with the right cupping the left. Brown glaze is applied to the robe and tall pointed boots; the hands are glazed white. The figure measures $25.2 \mathrm{~cm}$ high (Figure 10:1 and Figure 31).

Type $\mathrm{C}$ ( 6 items): The design is basically the same as Type B, except that the hands are tucked inside the sleeves. M7:22 has a large head, disproportional to the body. The folded hat is lined; the turban is high but not segmented. The figurine has a flat face, small eyes, sharp nose and slightly curled lips. The robe and boots are glazed brown. The height is $27 \mathrm{~cm}$ (Figure 10:2 and Figure 32). M7:6 has a hat that is folded into a two-part turban. This figurine wears a white robe with round collar, straight lapels and narrow sleeves. The robe falls below the knee, and is tied at the waist. The figurine wears pointedtoe tall boots. The hands, cupped together in front of the chest, are hidden inside the sleeves. The robe is glazed white with a slight tint of aqua. M7:6 is $22.4 \mathrm{~cm}$ high (Figure 10:4 and Figure 33). The robe and boots of M7:5 are glazed brown. It measures $21.8 \mathrm{~cm}$ high (Figure 34).

$\mathrm{Hu}$-image figurine ( 1 item: M7:1): The double braids are criss-crossed on the back of the head. The figurine has plump cheeks, wide forehead, wide nose and thick lips, which are typical characteristics of the $\mathrm{Hu}$ people. The hands, cupped in front of the chest, are tucked inside the sleeves. The figurine wears a purple-brown robe with round collar, straight lapels and narrow sleeves. The robe falls below the knees, and is tied at the waist. The figurine wears tall boots with pointed toes. The robe is glazed. The height is $24.6 \mathrm{~cm}$ (Figure 10:3; Figures 35 and 36).

\section{Animal Figurines}

There are four animal figurines, including horses, a cow and wild geese.

Horse figurine ( 1 item: M7:31): Found in the passage. It is standing, without horse gear. The head is slightly lifted and the ears are broken; the mane is trimmed and the tail is tied into a bow. The whole body is glazed brown; the forehead, mane and tail are glazed white; there are solidified droplets of glaze under the belly. The figurine is $22.7 \mathrm{~cm}$ long, with a remaining height of $18.2 \mathrm{~cm}$ (Figure 11:1 and Figure 37).

Cow (1 item: M7:36): Found in the passage. The damage is rather extensive. The figurine is in a standing position, with head slightly raised, short horns, and the end of the tail attached to the left haunch. Brown glaze is applied on a white glaze base; the horns are glazed green. There is more extensive chipping of the glaze on this figurine. It is $17.2 \mathrm{~cm}$ long and $11 \mathrm{~cm}$ high (Figure 11:2 and Figure 38).

Wild geese figurines ( 2 items): Both come from the first eastern niche. Their shape and other characteristics are similar. They stand on circular bases. Each has a flat, wide beak, small round eyes, and wing feathers. The beak, neck and body of M7:14 are glazed brown; the head is glazed white with a stripe of blue on top of the head. Dots of blue glaze are applied to the base of the beak. The wings and the tail are covered with mixed blotches of brown, white and green glaze. The figurine is $16.4 \mathrm{~cm}$ long and $15.5 \mathrm{~cm}$ high (Figure 11:3). The head, neck and body of M7:15 are glazed white. The beak and foot are glazed brown. A stripe of blue glaze was applied to the top of the head; dots of blue glaze are applied to the base of the beak. The wings and tail are glazed in mixed blotches of brown, white, green, and blue. The 
entire length is $15.2 \mathrm{~cm}$, and the height is $18.1 \mathrm{~cm}$. (Figure 11:4).

\section{Models}

The following three items were all unearthed from the first western niche.

Mill ( 1 item: M7:9): It has a round surface. It is composed of a runner stone, a bed stone, and a base. It looks like a two-level circular stand. The runner stone and the bed stone are the same size. There are two holes at the center of the runner stone, which has a groove on the outer edge. There is no base, and it is hollow in the middle. The whole implement is glazed yellow and green, except for the bottom. The top diameter measures $7.8 \mathrm{~cm}$, the bottom diameter measures $8.9 \mathrm{~cm}$, and the height is $6.1 \mathrm{~cm}$ (Figure 12:1 and Figure 39).

Trip hammer ( 1 item: M7:7): It is made up of two parts: the base and the treadle pestle. The base is trapezoidal; at one end is a mortar with a round exterior and square interior, and at the other end is a square U-shaped pedal slot. The end where the mortar rests is narrower; in the middle are two racks supporting the device. The pestle is in a long hourglass shape and can be maneuvered on the stand. The end is cut at an angle to fit the slot in the pedal. The end of the pestle is shaped like an olive. The mortar, the slot, the stand and the end of the pestle are glazed green. The top and sides of the pestle are glazed yellow; the remaining surfaces are unglazed. The length is $15.6 \mathrm{~cm}$, width $6.8-7.6 \mathrm{~cm}$, and height $5.4 \mathrm{~cm}$ (Figure 12:6 and Figure 40).

Latrine (1 item: M7:8): Shaped like a house without a roof, it has a square plan view. Surrounded by walls on all sides with a narrow doorway at the front on one side. At the center of the front wall is a small square window. There is a square pit with an edge on all sides in the center of the base. A tile is slanted across the front edge of this pit as a flow diversion panel. The top of this tile directly faces the window in the front wall. The exterior of the walls is glazed brown and the top edges are glazed green, as are the pit edges and the tile panel. The remaining surfaces have no glaze. The length of the base is about $13 \mathrm{~cm}$, the doorway measures $2.3 \mathrm{~cm}$ wide, and the small window is $1.4 \mathrm{~cm}$ square. The height of the entire model is $8.5 \mathrm{~cm}$ (Figure 12:2; Figures 42 and 43 ).

\section{Vessels}

$Y u$-water pots ( 2 items): They have identical forms and specifications. Each has a dish-shaped mouth, a narrow neck, a rounded body, and a flat base with a false ring foot. Two bowstrings are incised on the shoulder. The glaze does not extend to the base, where white engobe is exposed. M7:13 was unearthed from the first west niche. The white base is dotted blue and green. The mouth diameter is $8.4 \mathrm{~cm}$, the body diameter is $14 \mathrm{~cm}$, the base diameter is $9.1 \mathrm{~cm}$, and the height is $11.8 \mathrm{~cm} . \mathrm{M} 7: 16$ is from the first east niche. The white base is dotted blue and the glaze looks like glass. The mouth diameter is $8.1 \mathrm{~cm}$, the body diameter is $12.9 \mathrm{~cm}$, the base diameter is $8.8 \mathrm{~cm}$, and the height is $11 \mathrm{~cm}$ (Figure 12:4 and Figure 41).

\section{(B) Pottery}

Pen-basins (4 items): All share the same form and characteristics: gray temperless pottery made on a potter's wheel. Two of them come from the entrance of the passage at the bottom of the ventilation shaft. The other two are from the grave chamber; they were broken but have been reconstructed in full. M7:29 has a curled rim, slightly rounded body that tapers toward a flat base. The mouth diameter is $22.8 \mathrm{~cm}$, the bottom diameter is $13.5 \mathrm{~cm}$, and the height is $10 \mathrm{~cm}$ (Figure 12:3).

Pagoda-shaped jars (2 items): Unearthed in the tomb, both are damaged and one has only the base remaining. M7:38 is composed of three parts: lid, guan-jar and stand. The lid is made of terra cotta clay. The spire-shaped knob is damaged. The jar 

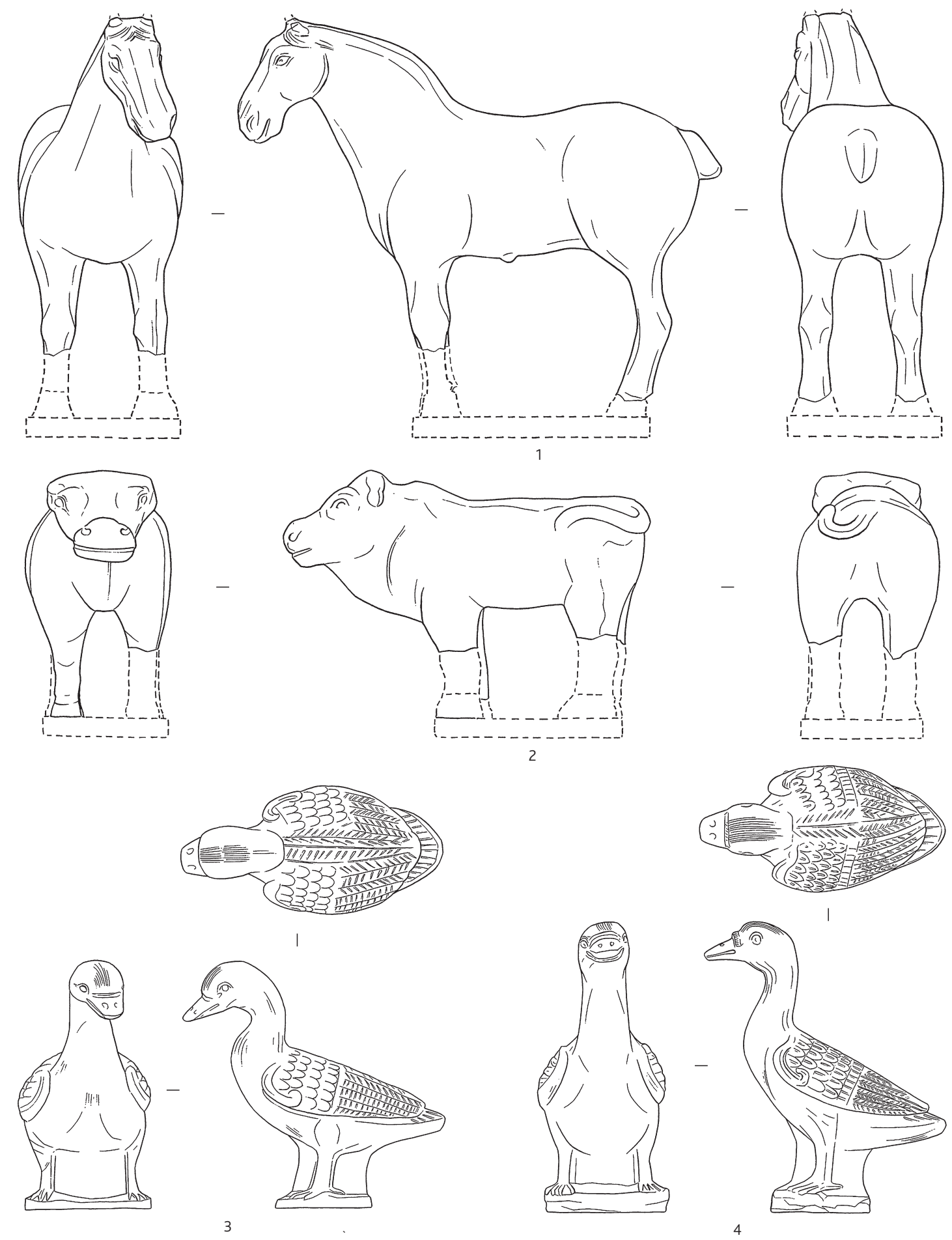

Figure 11: Tri-colored animals

1. Horse $($ M7:31) 2. Cow $(M 7: 36)$ 3, 4. Wild geese $(M 7: 14,15)(1,2$ scaled 1:3, 3, 4 scaled 1:4) 

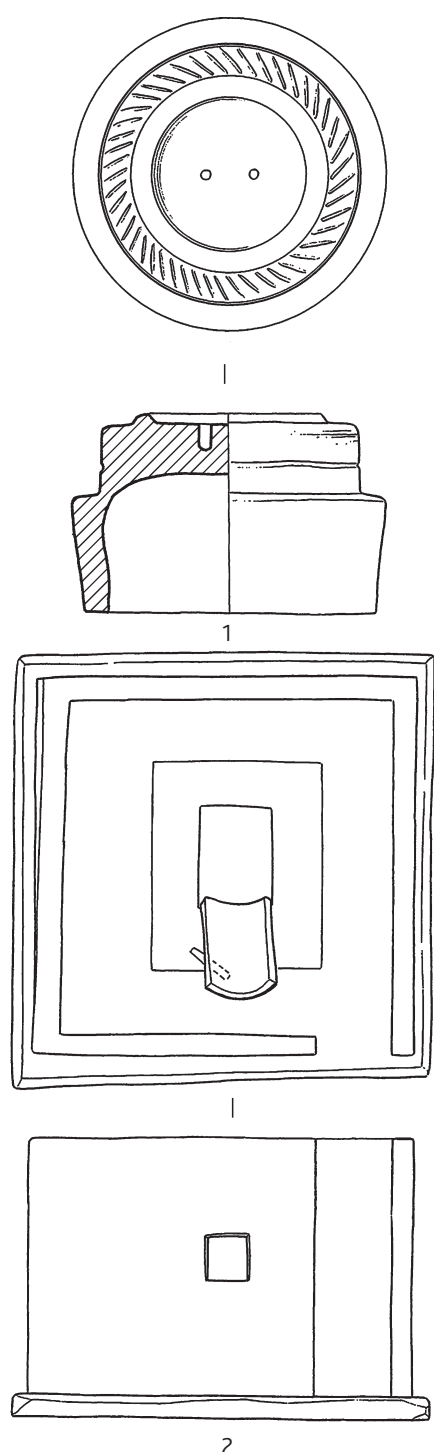
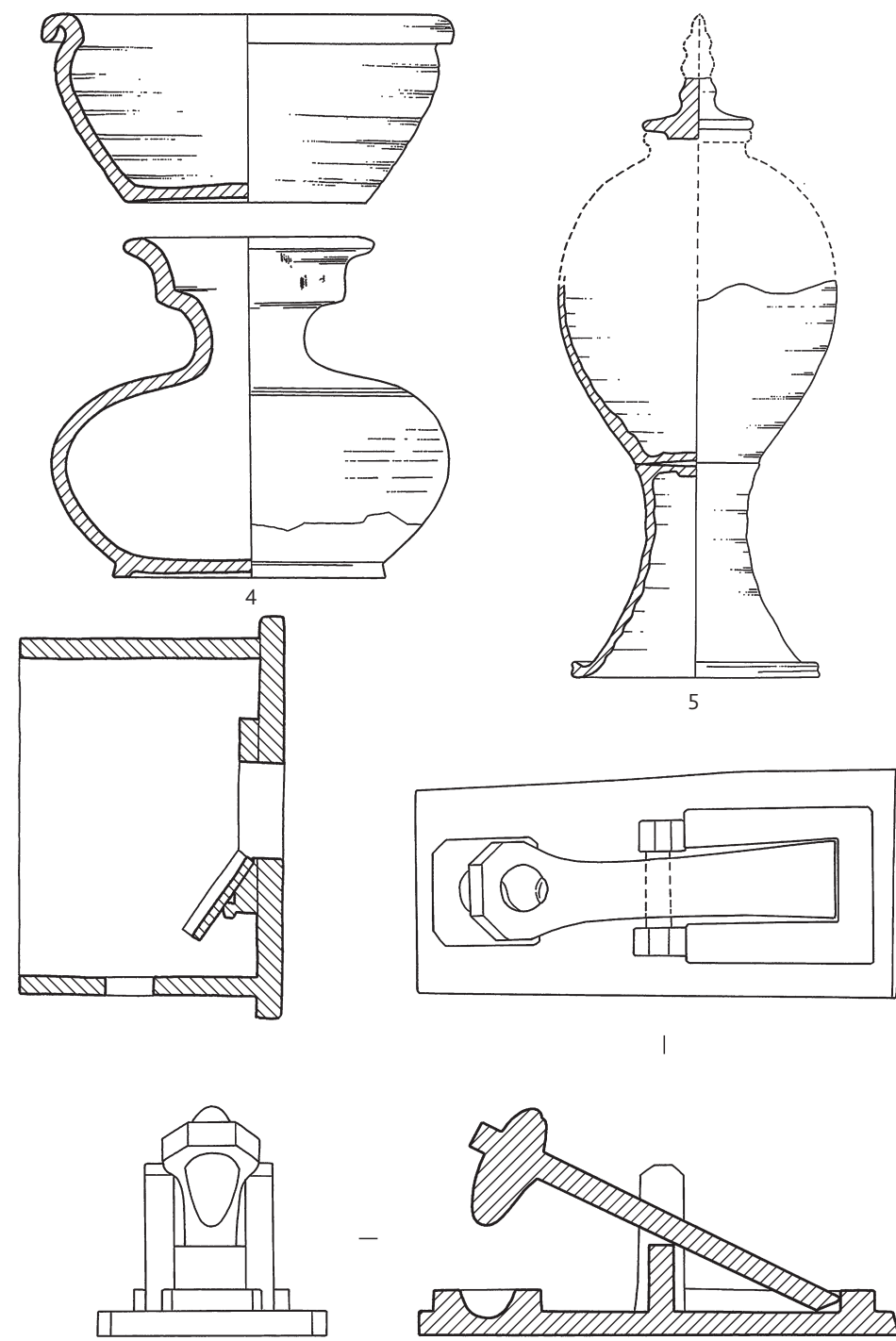

Figure 12: Unearthed artifacts

1. Tri-colored millstone (M7:9) 2. Tri-colored latrine (M7:8) 3. Pottery pen-basin (M7:29) 4. Tri-colored yu-water pot (M7:16) 5. Pagoda-shaped jar (M7:38) 6. Tri-colored pestle (M7:7) (1, 2, 4, 6 scaled 1:3; 3 scaled 1:5; 5 scaled 1:8)

is damaged and cannot be restored. It has a gray temperless texture, round body and small flat base. Red pastel colors are visible on the body. The base is trumpet-shaped with a flat top. The contours of the base extend outward from the top. The entire vessel is covered in a white slip, on which red lotus petals and cirrus patterns are painted. The remaining diameter of the lid measures $9.3 \mathrm{~cm}$; the height of the lid is $5 \mathrm{~cm}$. The remaining diameter of the base of the jar is $10.5 \mathrm{~cm}$; the jar is $14 \mathrm{~cm}$ high. The stand has a diameter of $10.3 \mathrm{~cm}$, and the base diameter is $21.4 \mathrm{~cm}$. It is $18 \mathrm{~cm}$ high (Figure 12:5).

Ink slab (1 item: M7:40): Only a corner remains, inscribed with the character 风 [wind]. It has a gray temperless texture and molded pointed feet. The remaining length is $9 \mathrm{~cm}$. 
The Tomb of the Yang Gui Couple of the Tang Dynasty in a Southern Suburb of Xi'an
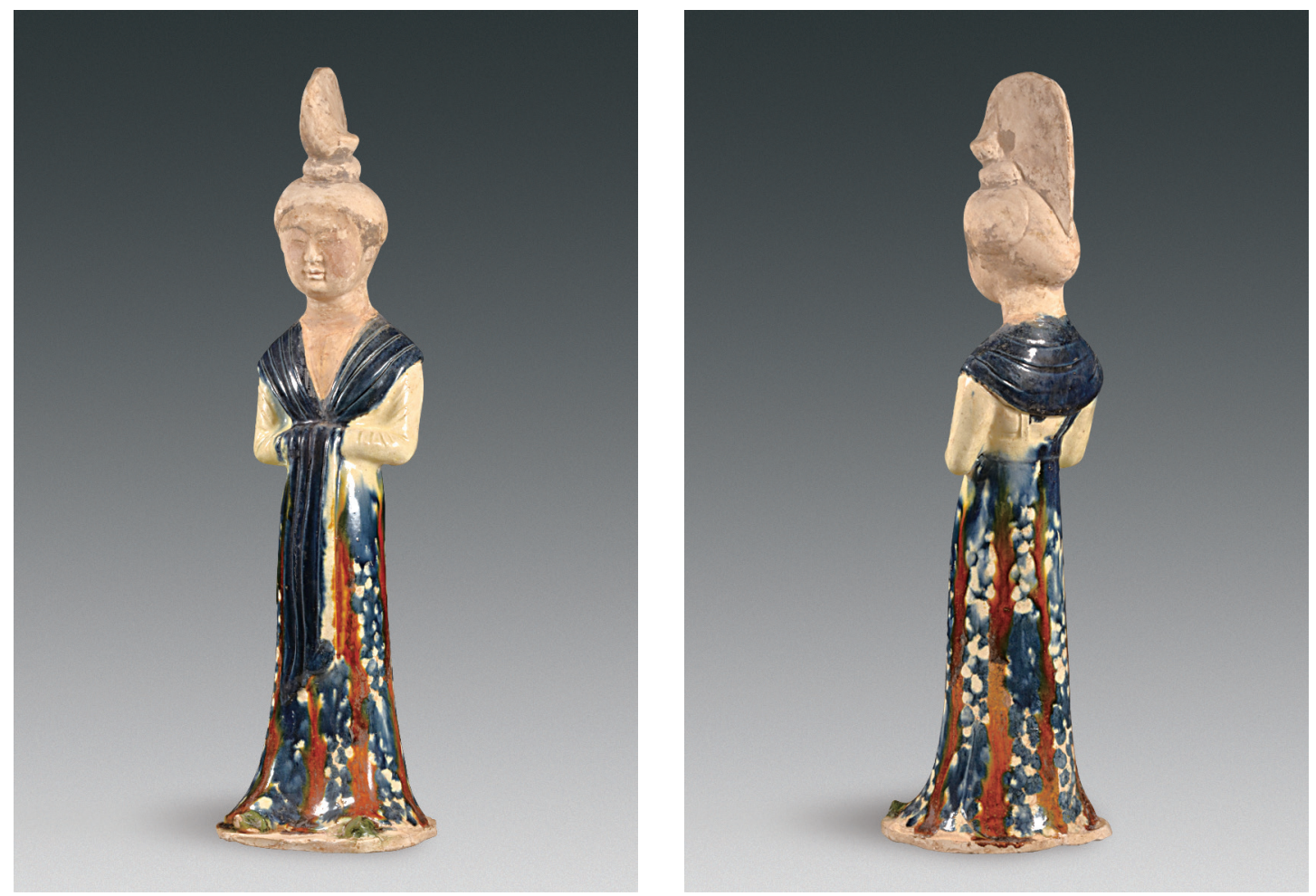

Figure 13: Tri-colored maid figurine (M7:4)

Figure 14: Tri-colored maid figurine (M7:4) (back view)
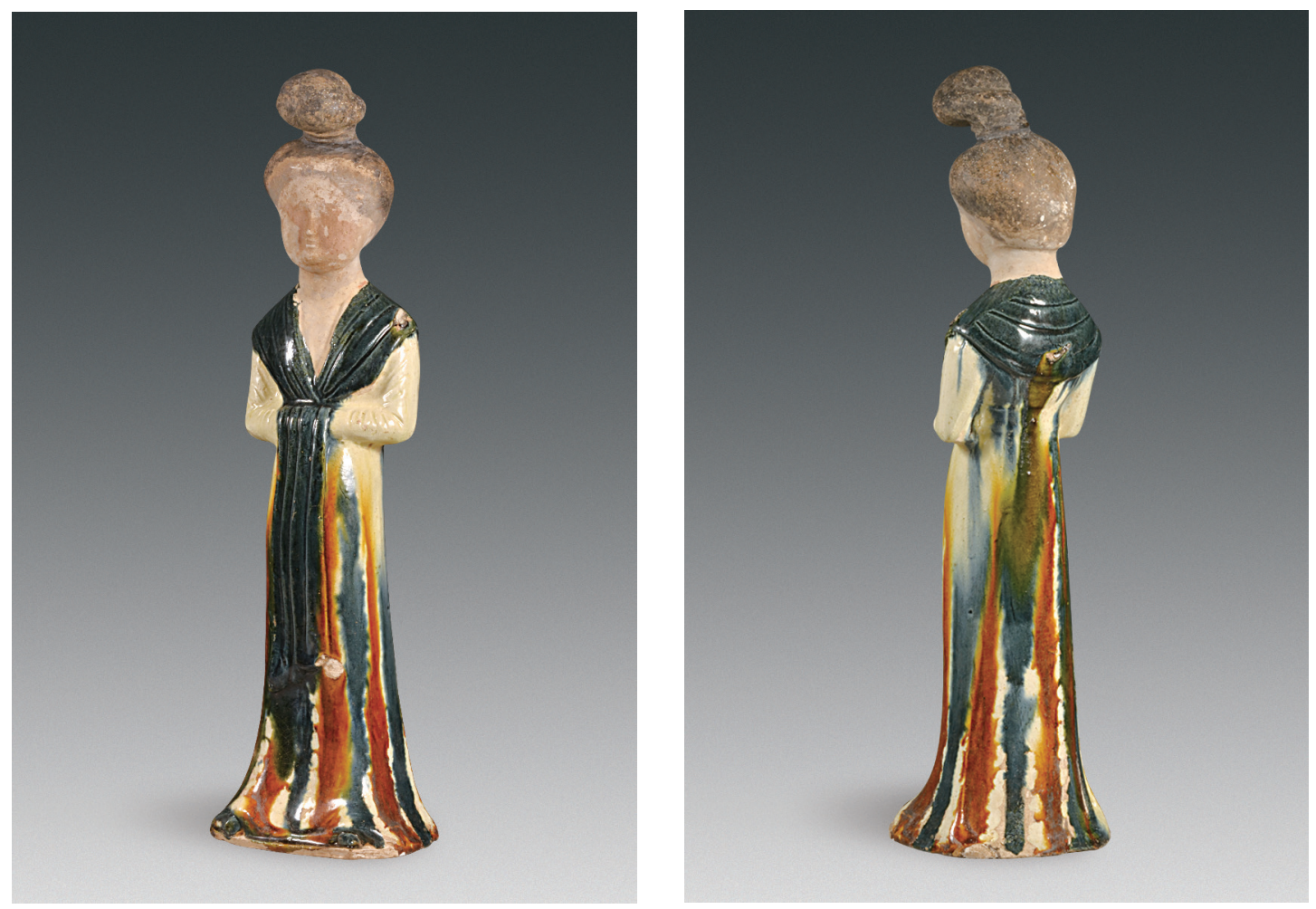

Figure 15: Tri-colored maid figurine (M7:17)

Figure 16: Tri-colored maid figurine (M7:17) (back view) 
Chinese Cultural Relics »Issue Number 1-4, 2018
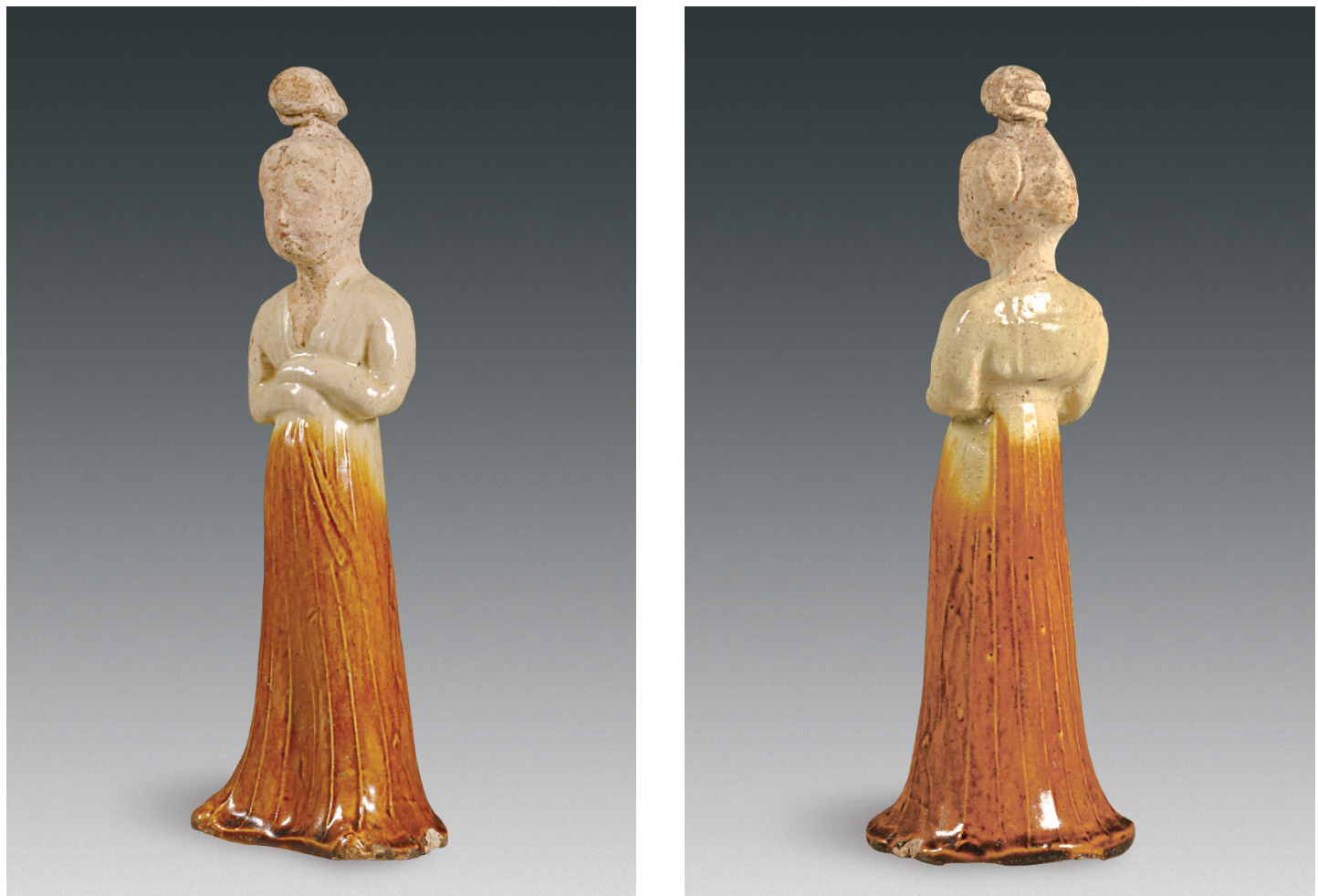

Figure 17: Tri-colored maid figurine (M7:3)

Figure 18: Tri-colored maid figurine (M7:3) (back view) •....................................

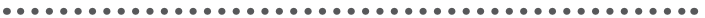
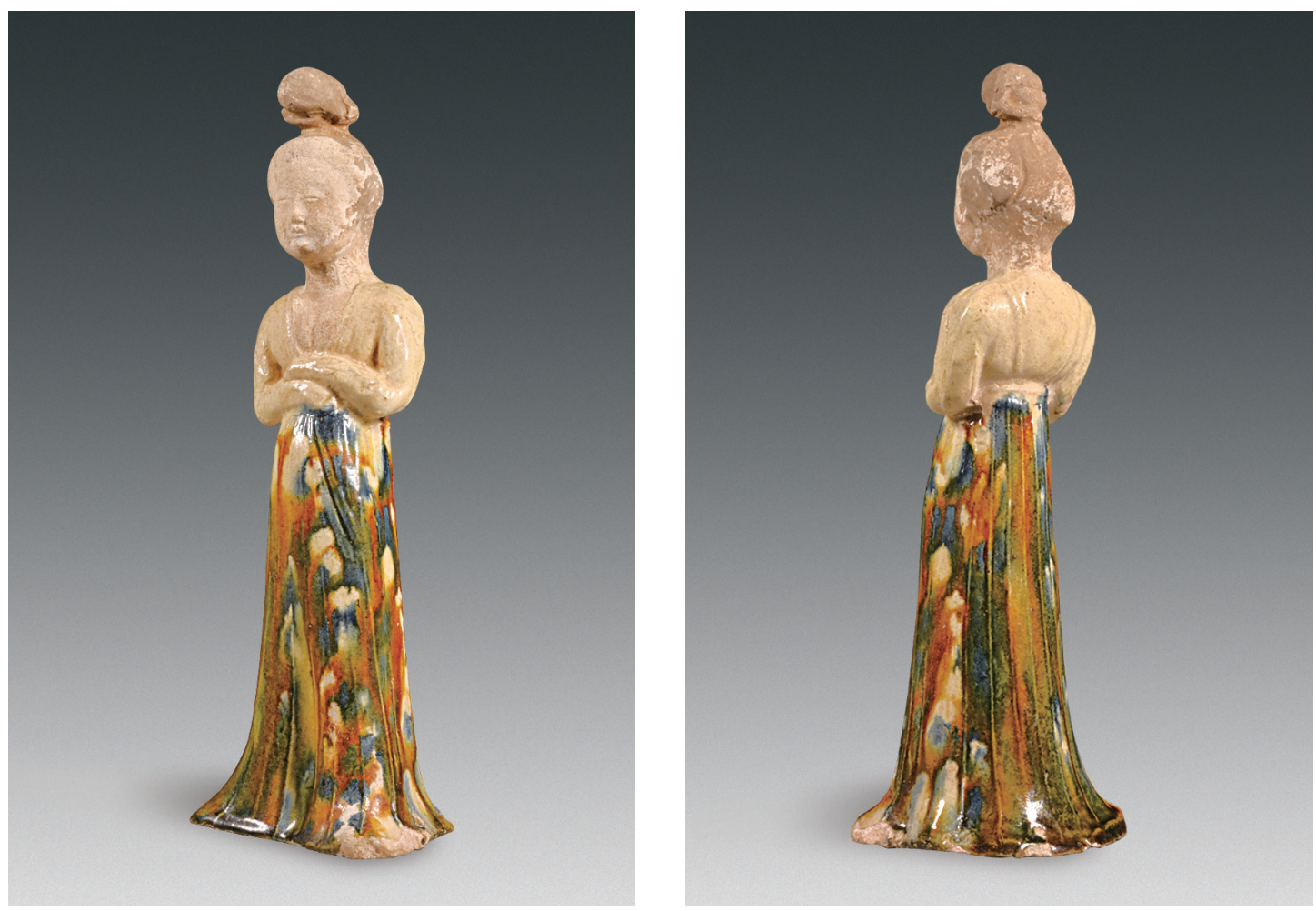

Figure 19: Tri-colored maid figurine (M7:24)

Figure 20: Tri-colored maid figurine (M7:24) (back view) [......................................... ............................................ 
The Tomb of the Yang Gui Couple of the Tang Dynasty in a Southern Suburb of Xi'an
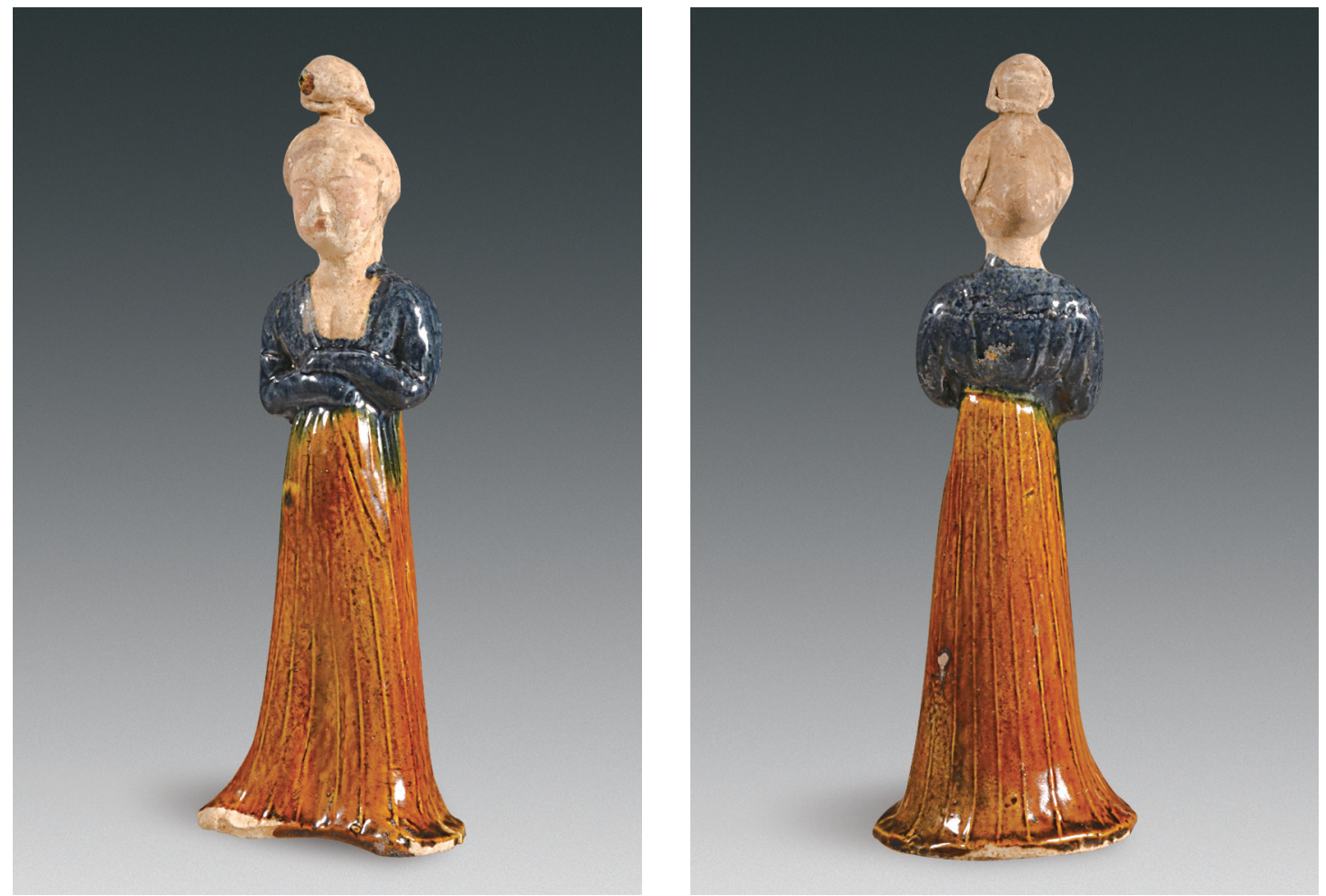

Figure 21: Tri-colored maid figurine (M7:27)

Figure 22: Tri-colored maid figurine (M7:27) (back view)

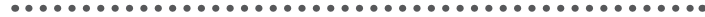
•.....................................
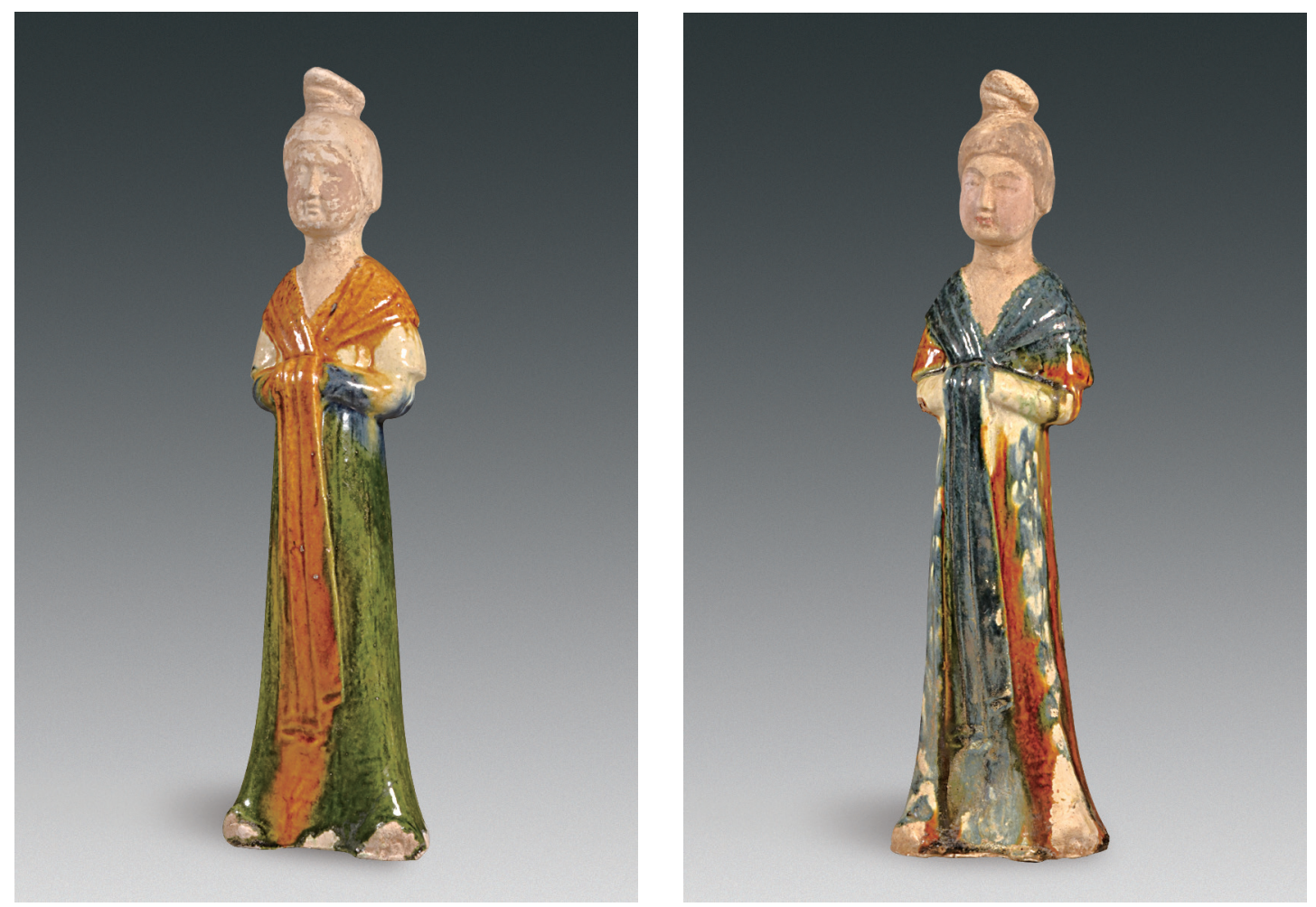

Figure 23: Tri-colored maid figurine (M7:2)

Figure 24: Tri-colored maid figurine (M7:18) 
Chinese Cultural Relics »Issue Number 1-4, 2018
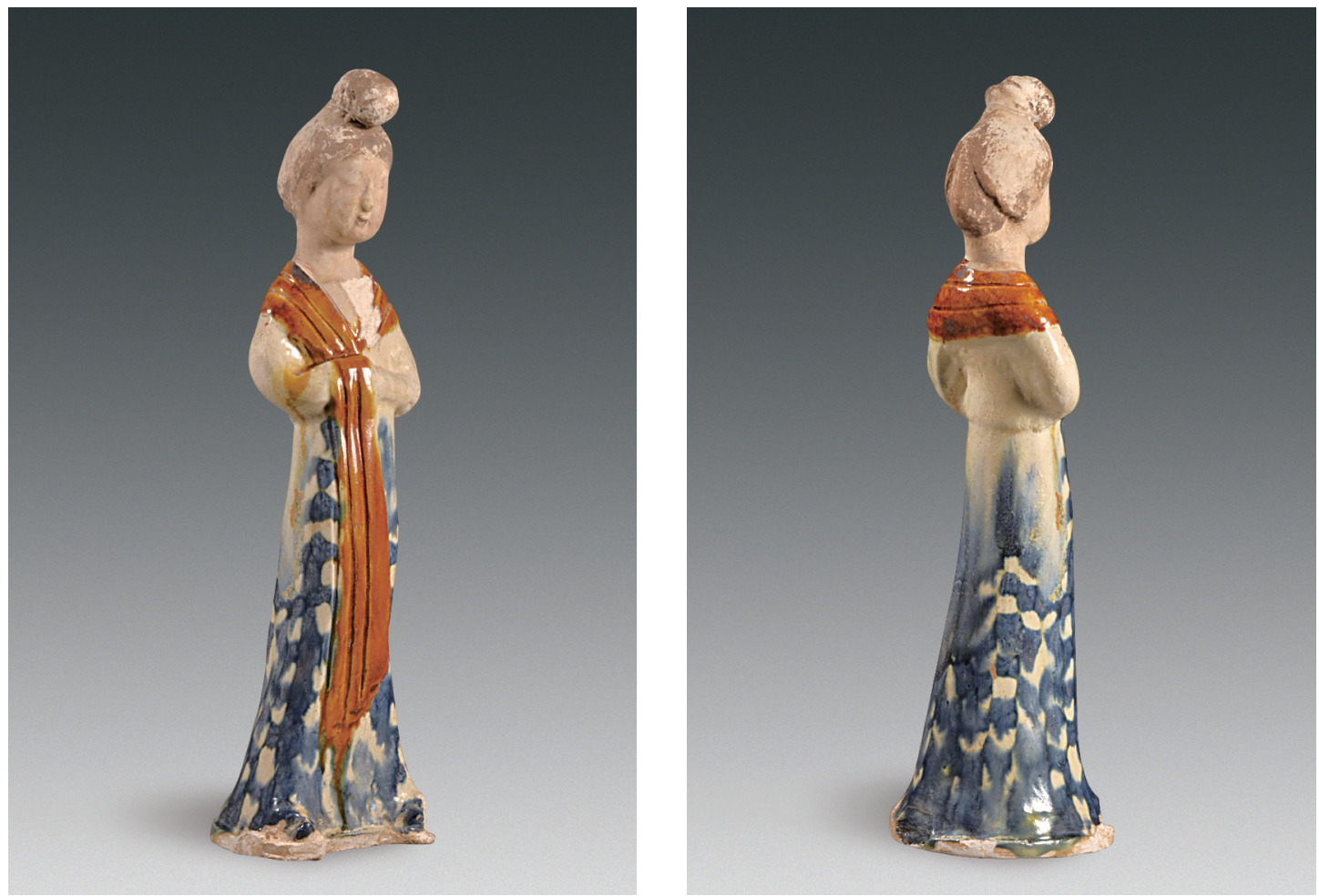

Figure 25: Tri-colored maid figurine (M7:21)

Figure 26: Tri-colored maid figurine (M7:21) (back view)
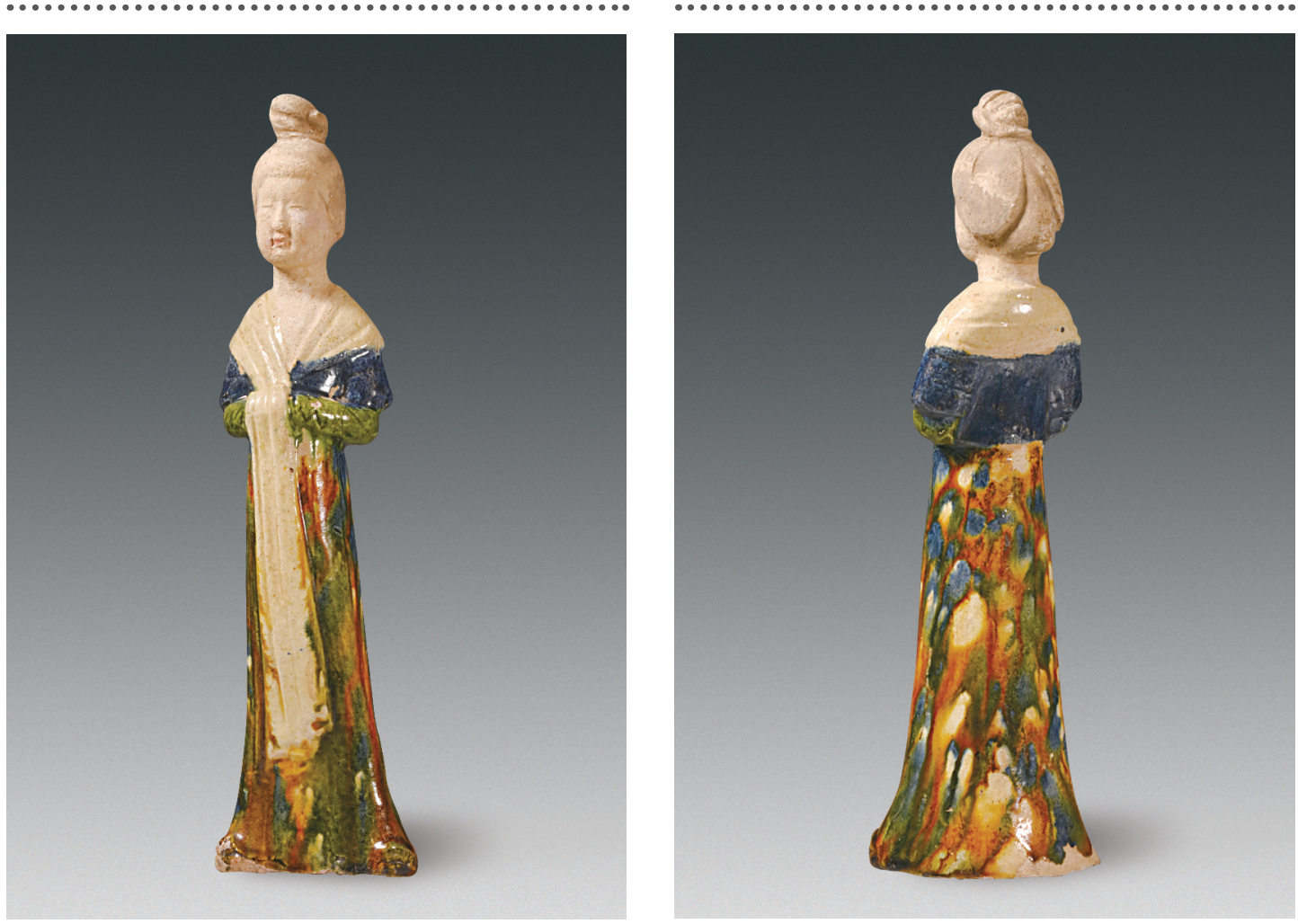

Figure 27 Tri-colored maid figurine (M7:26)

Figure 28: Tri-colored maid figurine (M7:26) (back view) 
The Tomb of the Yang Gui Couple of the Tang Dynasty in a Southern Suburb of Xi'an
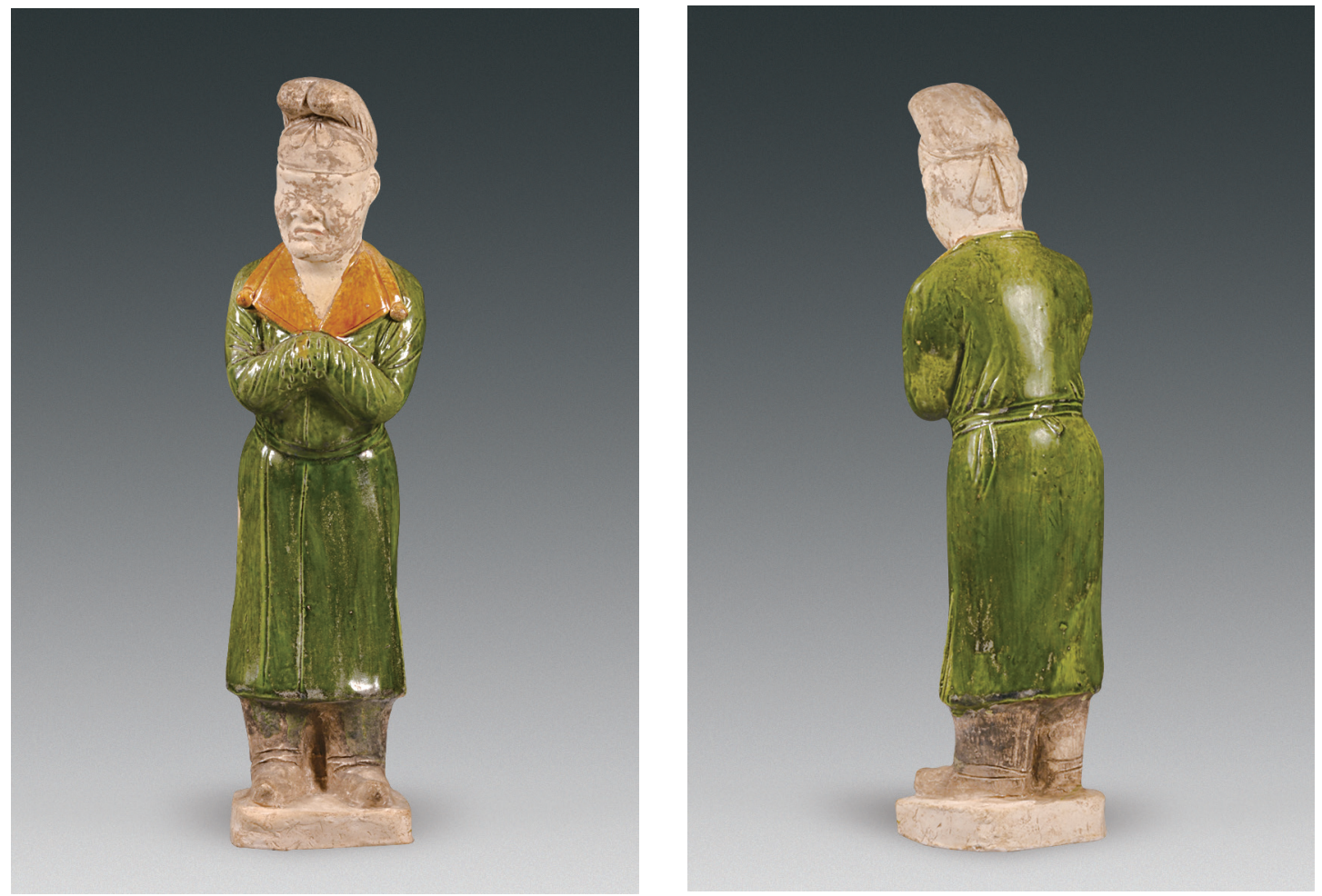

Figure 29: Tri-colored male servant figurine (M7:10)

Figure 30: Tri-colored male servant figurine (M7:10) •....................................

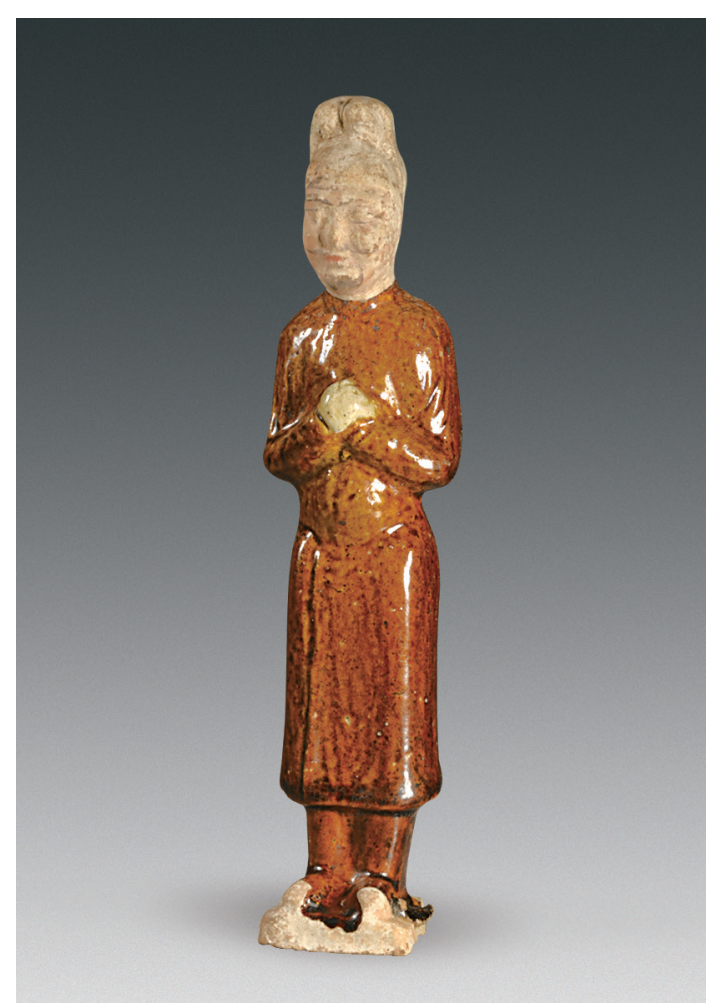

(back view)

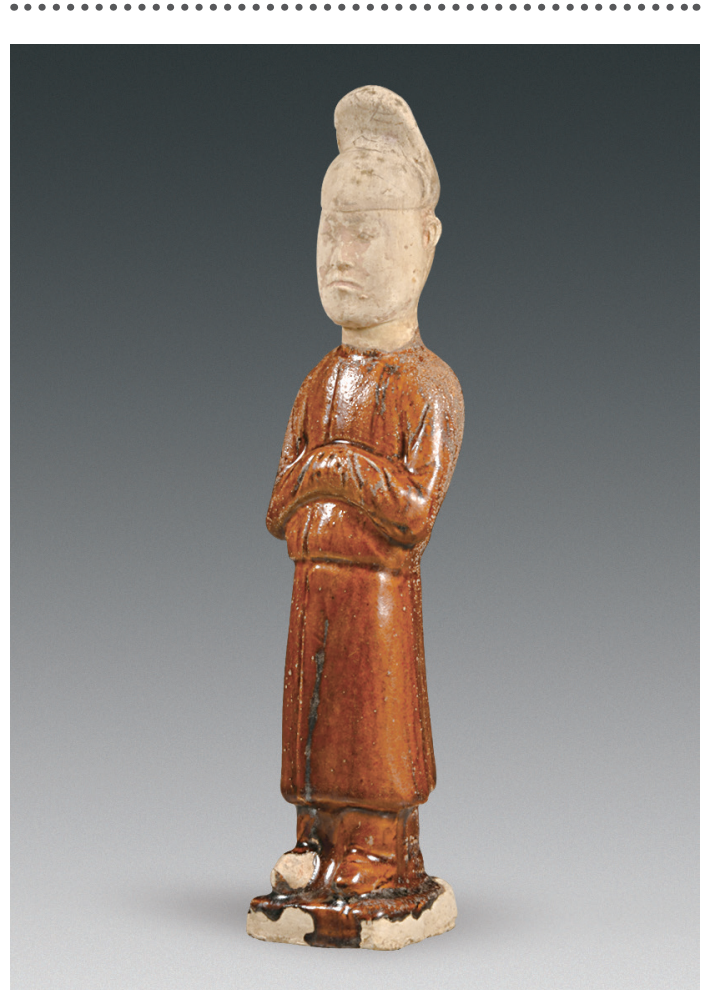

Figure 31: Tri-colored male servant figurine (M7:20) Figure 32: Tri-colored male servant figurine $(\mathrm{M} 7: 22)$ 
Chinese Cultural Relics »Issue Number 1-4, 2018

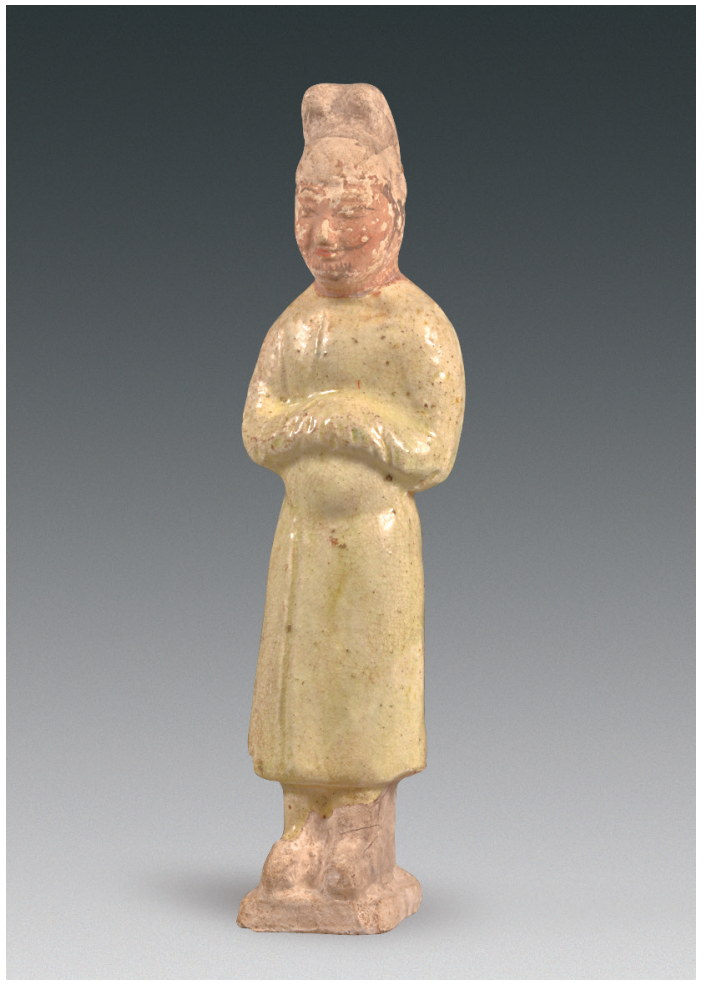

Figure 33: Tri-colored male servant figurine (M7:6)

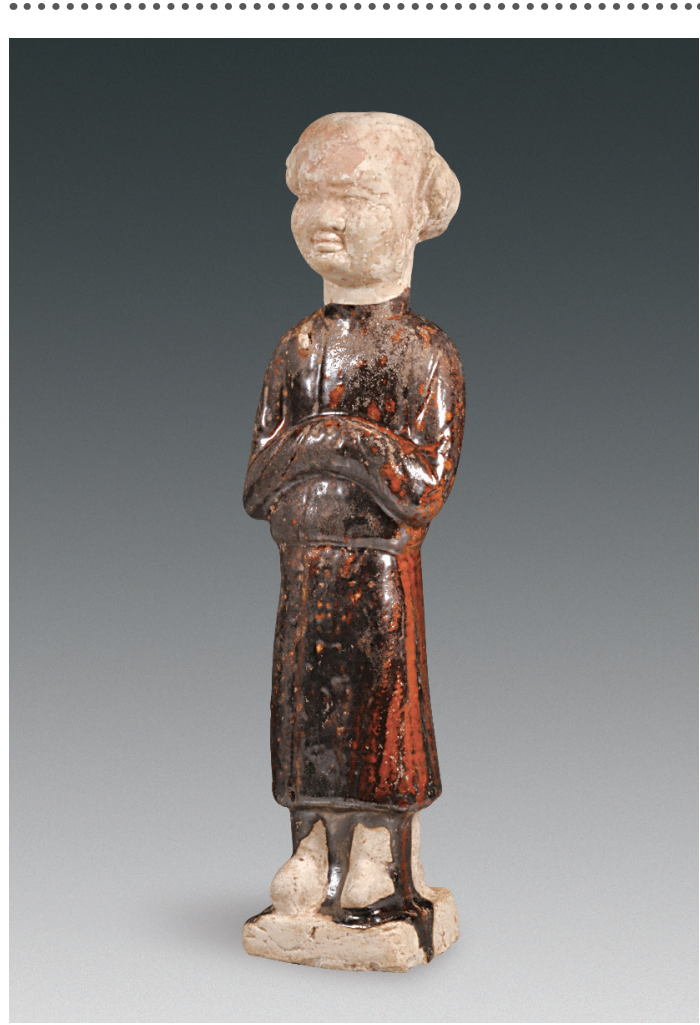

Figure 35: Tri-colored Hu figurine (M7:1)

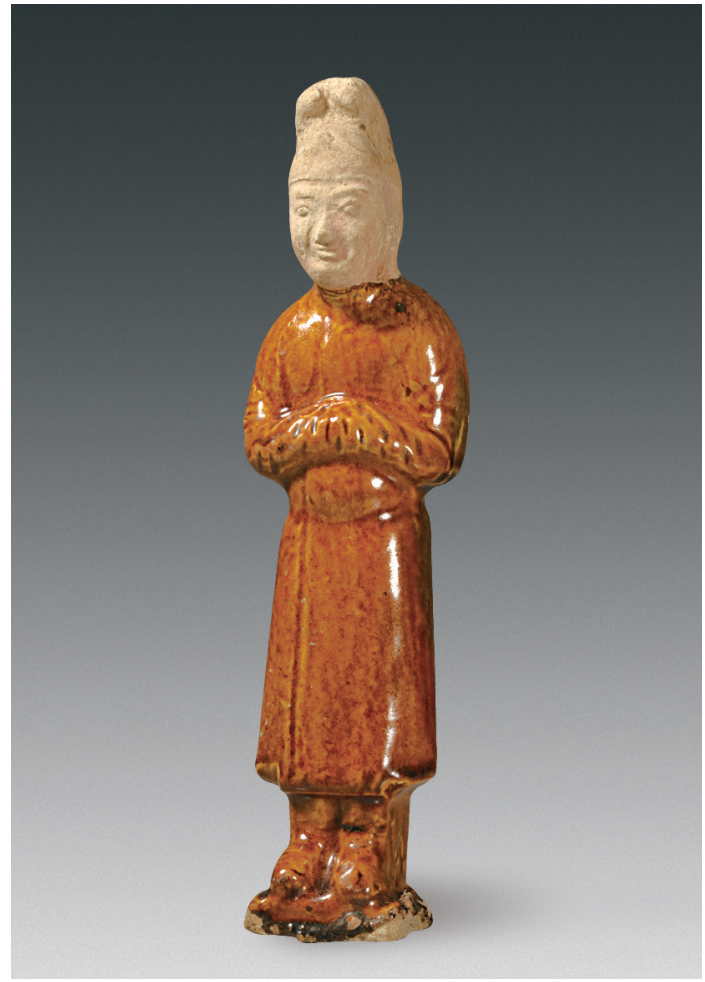

Figure 34: Tri-colored male servant figurine (M7:5)

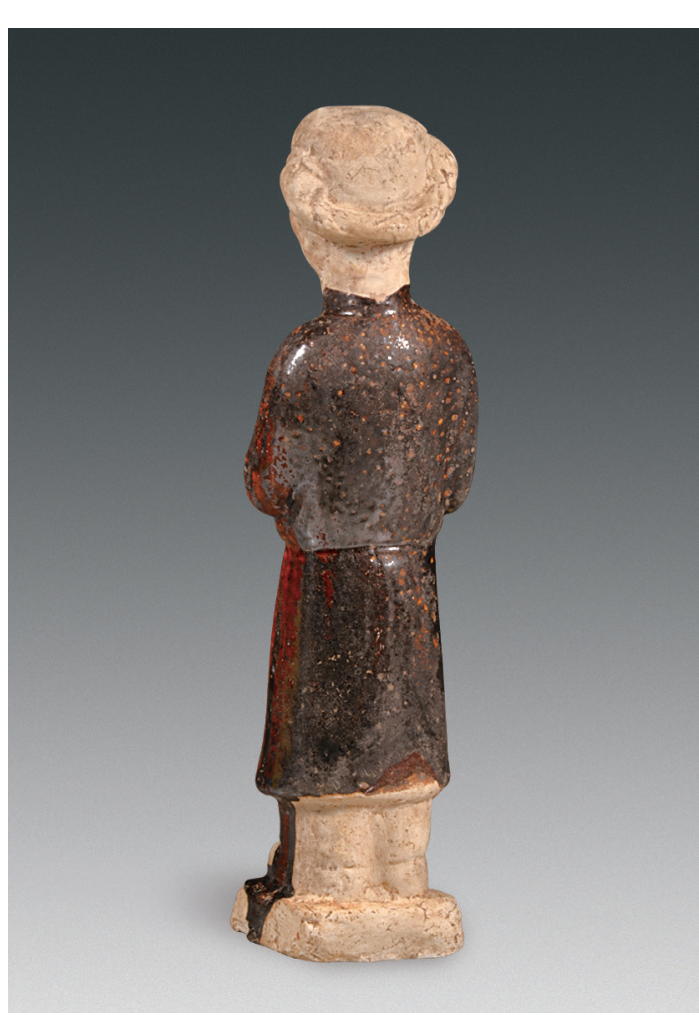

Figure 36: Tri-colored Hu figurine (M7:1) (back view) •................................... 


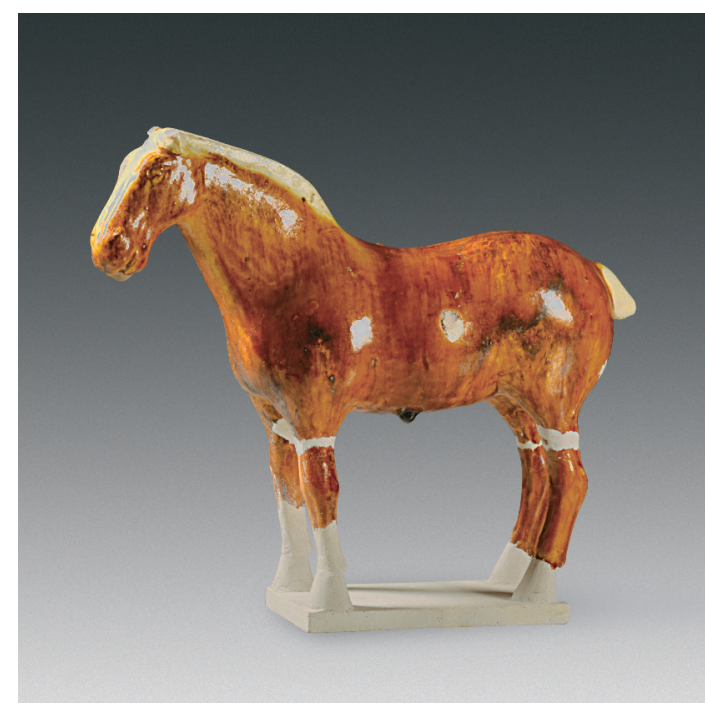

Figure 37: Tri-colored horse figurine (M7:31)

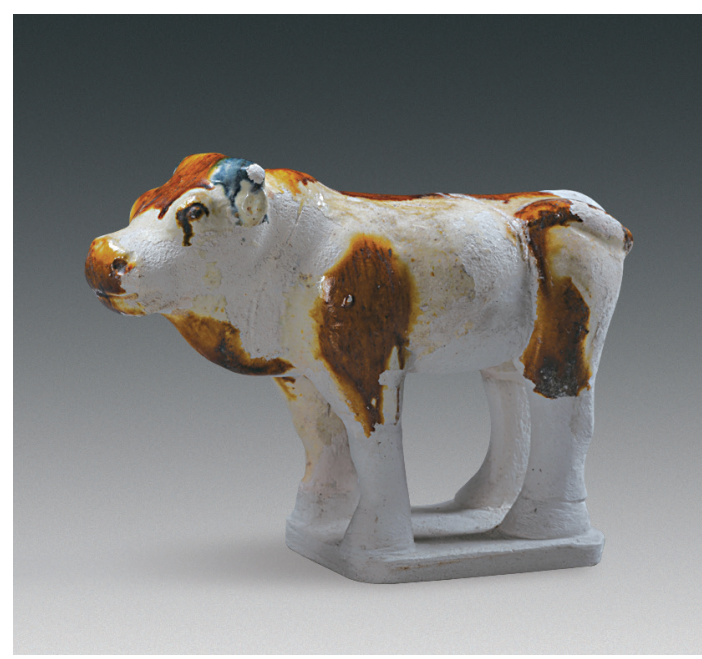

Figure 38: Tri-colored cow figurine (M7:36)

\section{(C) Miscellaneous}

Coins ( 1 set of 27 items): They are all inscribed Kaiyuan tongbao [Kaiyuan, reign period of Emperor Taizong of the Tang dynasty, 713-741 CE], and were found in the hands and mouths of the tomb occupants. The inscriptions of M7:34-1 are clear and neat, the strokes are carved deep, and the coin was cast very well. The left end of the lower horizontal stroke

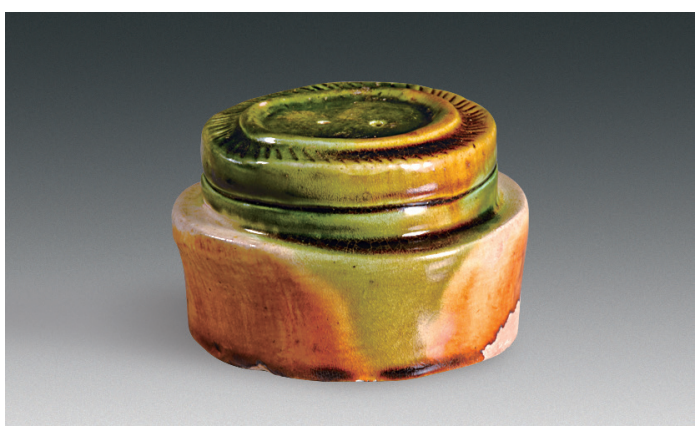

Figure 39: Tri-colored millstone (M7:9)

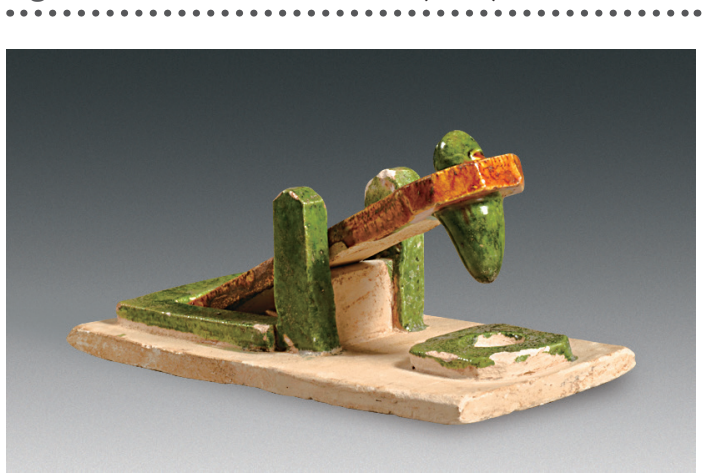

Figure 40: Tri-colored trip hammer (M7:7)

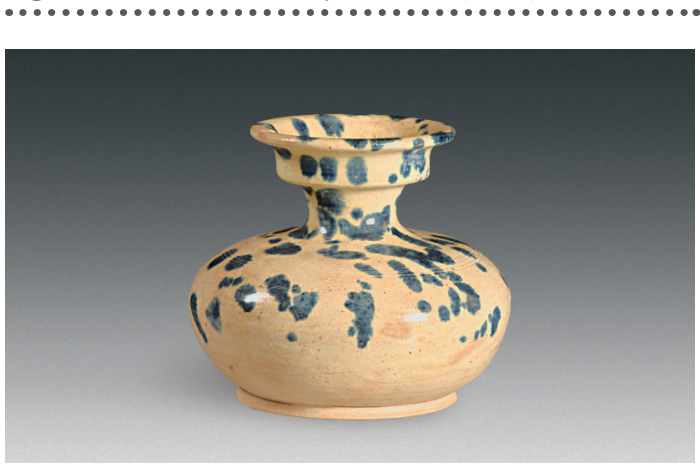

Figure 41: Tri-colored yu-water pot (M7:16)

of the character 元 $[y u a n]$ is raised. The diameter is $2.55 \mathrm{~cm}$, and it weighs 1.3 grams.

Bronze persimmon calyx-shaped ornament ( 1 item: M7:48): This hexagonal ornament is lightweight, carved hollow, and gilded on one side. The diameter is $1.8 \mathrm{~cm}$ (Figure 44).

Iron scissors (1 pair: M7:46): Seriously corroded and damaged. The original object appears 


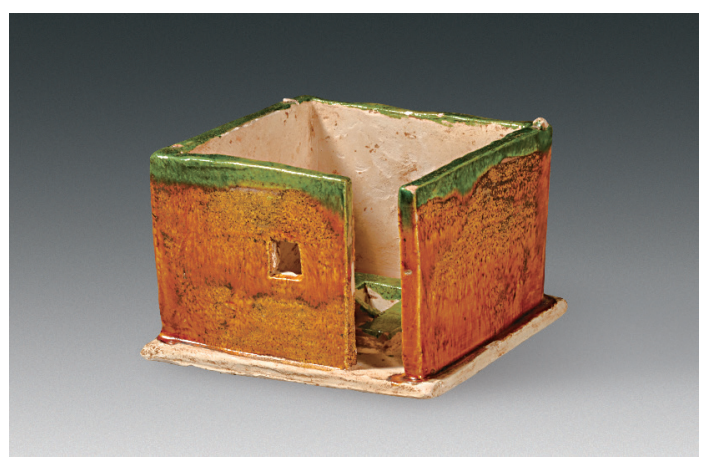

Figure 42: Tri-colored latrine (M7:8)

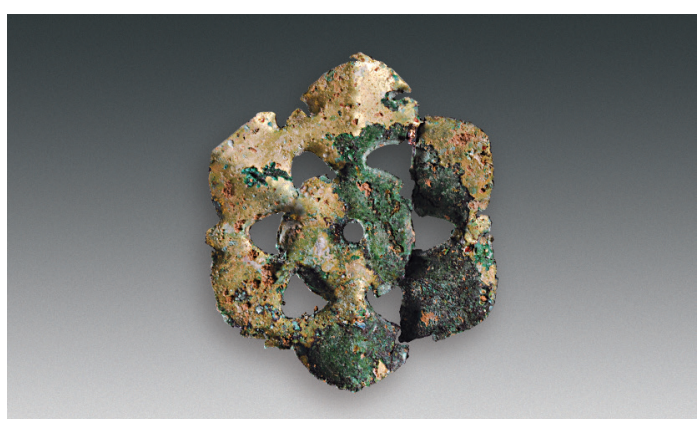

Figure 44: Bronze persimmon calyx-shaped ornament (M7:48)

to have been shaped like a figure 8 . The remaining length is $28.5 \mathrm{~cm}$.

Glass beads (1 set of 17 items) M7:35 has emerald green glaze texture. The beads are tubular and have different sizes. The outer diameter is 0.25 $0.3 \mathrm{~cm}$, and the length is $0.1-0.4 \mathrm{~cm}$ (Figure 45 ).

Glass ball (M7: 47): Brown glaze texture, hollow in the center. The external diameter is $1.5 \mathrm{~cm}$.

Tombstone cover (1 item: M7:33): Located inside the third ventilation shaft, outside the sealed gate of the passage. When it was unearthed, the cover was on top of the tombstone, with the upper part oriented southward. The cover is made of bluestone and is $58 \mathrm{~cm}$ high, $57 \mathrm{~cm}$ wide and $12 \mathrm{~cm}$ thick. The longest sides of the trapezoidal roof are $36.5 \mathrm{~cm}$ long. Three lines of characters that read "Epitaph of the Departed Lord Yang of the Great Tang Dynasty" are inscribed in seal script on the flat top. Each line has

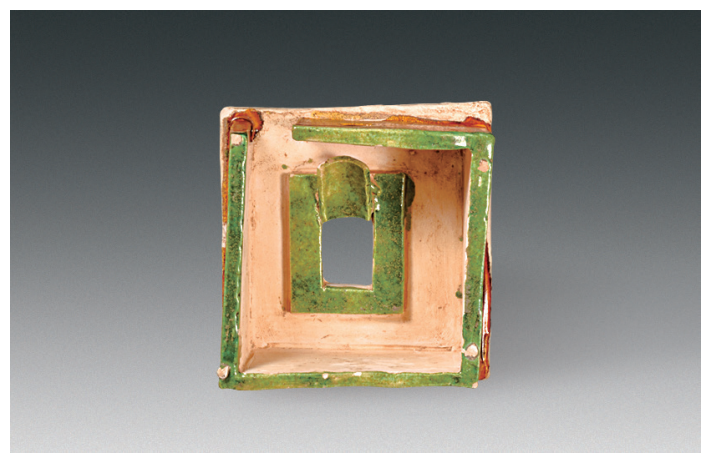

Figure 43: Tri-colored latrine (M7:8) (top view)

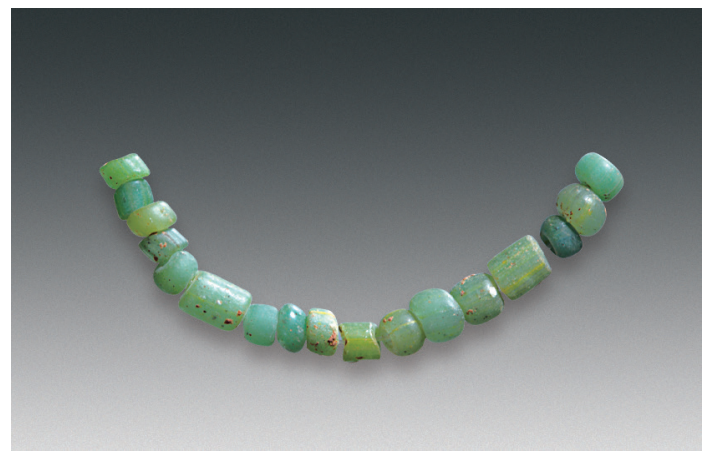

Figure 45: Glass beads (M7:35)

three characters. Various auspicious animal motifs are carved on the four slopes: The upper panel depicts a lion devouring a deer, the lower panel depicts a standing vermillion bird with spread wings, and the left and right panels feature roaring and prancing lions, lined with flowers and entwined twigs. Wave patterns are incised on all four sides (Figure 46). The tombstone measures $57.5 \mathrm{~cm}$ in both height and width. It is $11.5 \mathrm{~cm}$ thick. It is engraved with a thin line chess grid pattern. Twenty-two lines of clerical script are inscribed, and a full line contains 23 characters, making a total of 486 characters. Zodiac patterns are cut on the four borders. Zodiac signs in animal form are located in the kunmen-pointed arches, lined with a ruyi-cloud scroll pattern. The Rat is in the middle of the upper side, and the zodiac is arranged clockwise (Figure 47). The inscription reads as follows: 
Here follows the epitaph of the Departed Assistant Magistrate of Fangcheng County of Tangzhou Prefecture and the Adjutant of Zizhou Prefecture of the Great Tang dynasty: / The forbidden name of the Lord was Gui, courtesy name Xiang. He was a native of Hongnong Commandery. Looking into his distinguished and distant lineage, he was descended from / the clan that flourished to the west of the Yumen Pass during the Han dynasty. Although post changes and discharges divided the lineages in the territory and disrupted their connections, their spiritual roots are essentially the same. The Lord's great-grandfather, named Dao, / resided in a secluded place but kept his aspirations high. He dressed plainly but was content in poverty. He was lightly garbed in ceremonial dress and cap to give thanks. He reached enlightenment and passed away. The Lord's grandfather was then appointed Magistrate of Zigui County, Guizhou Region, during / the Sui dynasty. $\mathrm{He}$ loved the people and was highly skilled. He was known as a good magistrate at the time. / He was incorruptible and respected the customs. The administration was harmonious and people were compliant. The Lord [Yang Gui] was appointed Assistant Magistrate of Fangcheng County, Tangzhou Prefecture. He did not desecrate the previous system, / and was able to make the family great. His virtuous deeds were recognized and became known. Glorious commendations were given and received, which he thought were illustrious but impractical. / There is also an end to life. He passed away in his private residence in the village of Ninghua in the capital on the ninth day of the twelfth moon in the second year of the Yifeng reign period [Jan. 7, $678 \mathrm{CE}$ ] and was temporarily buried at
Figure 46: Tombstone cover (M7:33) Rubbing of lid (scale 1:6)

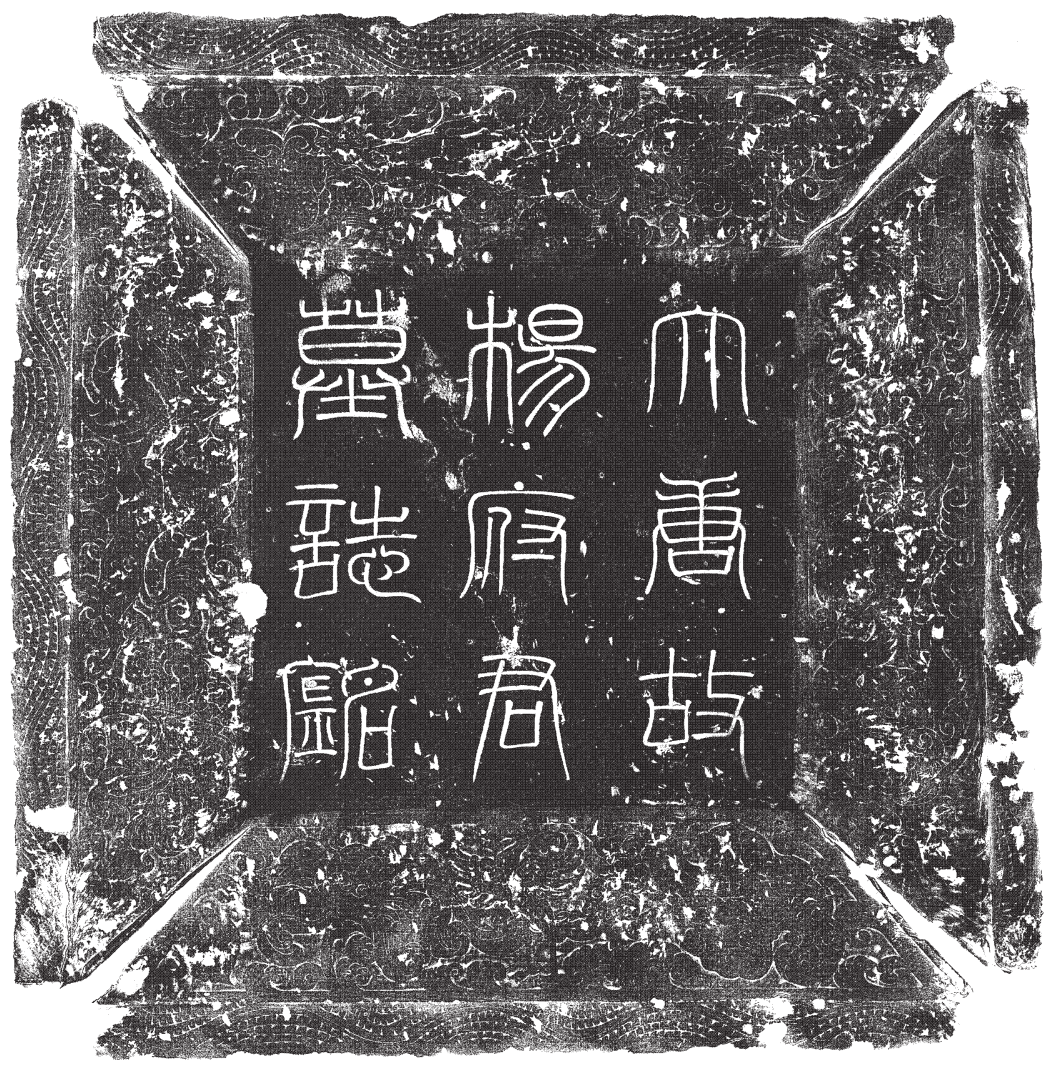




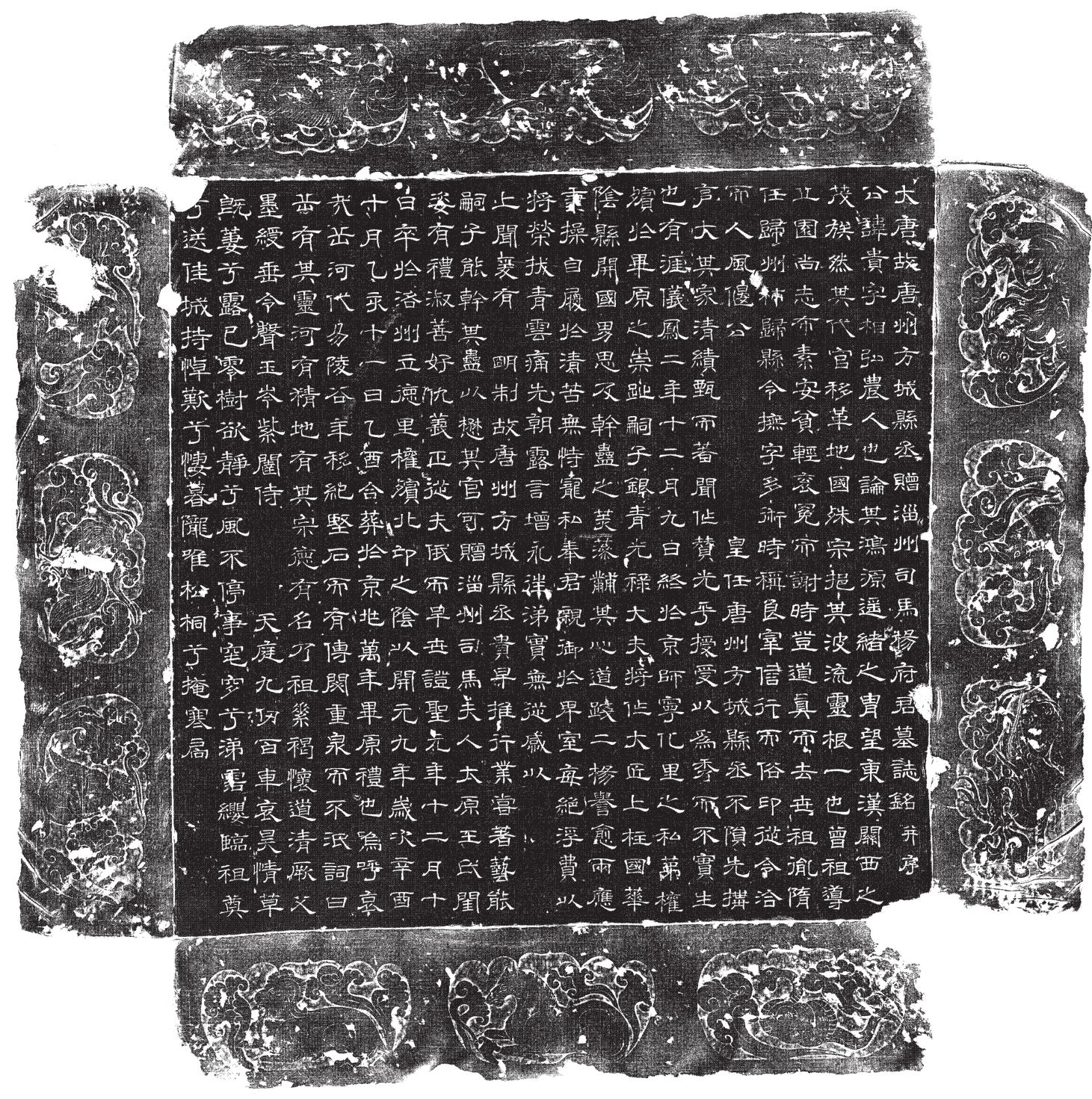

Figure 47: Rubbing of epitaph (M7:33) (scale 1:5)

a revered site in Biyuan area. His successor, Siji, bestowed upon him the titles of Grand Master for Splendid Happiness with Silver Seal and Blue Ribbon [Yinqing Guanglu dafu 银青光禄大夫], Chamberlain for the Palace Buildings [Jiangzuo dajiang 将作大匠], Upper Pillar of the State [Shang Zhuguo 上柱国] and Dynasty-Founding Baron / of Huayin County, [in honor of] the virtuous deeds of his father, the resplendence of his heart. The path is carried on by the two Yangs. / Both have more than fulfilled their reputation. [Yang Gui] followed strict conduct and lived an austere life. He did not reply on favors and illicit dealings. He served the emperor and managed affairs personally from a humble chamber and always refrained from incurring unnecessary expenditures. / He was about to receive a high promotion, but it is sad that his life was fleet- 
ing like the morning dew. As words about the netherworld multiply, tears truly cannot be controlled. As the reports above [about Yang Gui's virtues] reached the emperor, they led to honest governance. Thus the [officials of] Fangcheng County, Tangzhou Prefecture helped the Lord [Yang Gui] by launching industries and creating careers at an opportune time. / He studied writings and cultivated the arts. His eldest was able to follow his father's endeavors and put in the hard work for the position in order to be honored as the Adjutant of Zizhou Prefecture. / [Yang Gui's] wife née Wang from Taiyuan was well composed and had a good appearance. She was a virtuous and kind partner. She was principled and stood in full support of her husband. Her time was short, and she died early in the Village of Lide in Luozhou [i.e. Luoyang] City on the tenth day of the twelfth moon of / the first year of the Zhengsheng [i.e., Tiancewansui] reign period [Nov. 21, $695 \mathrm{CE}$ ], and was temporarily buried in the Beimang area. She was then buried together [with Lord Yang Gui] for eternity at the capital magistracy of Biyuan on / the eleventh day of yiyou in the tenth moon of yihai in the ninth year of the Kaiyuan reign period, which was the year of xinyou in the sexagenary cycle [Nov. 5, $721 \mathrm{CE}$ ]. This [epitaph] completed the rite. / Alas! Mountains and rivers change, and hills and valleys shift as the years go by. Let the accounts of their lives be inscribed on a solid stone so that they may not be forgotten even when they rest sealed in the netherworld. It was written in poetry: /

The mountains have their spirits and the rivers have their goblins. The lands have their ancestors and virtuousness has its name. Such are our ancestors, who dressed themselves plainly and / carried aspirations for an honest path; he who was our father used the authority endowed by his seal and his sash to issue his edicts. The jade hills and the royal gates await at the celestial court; nine fathoms of innumerable carts mourn their towering spirits. The grass / has withered and the dew has dried up! The trees wish to be still, yet the wind will not stop blowing! Tears wet our tassels as we attend to the affairs of the grave. We approach our ancestors / to make offerings and send them off into the cemetery. Sighs of mourning and deep sorrow fall at dusk at the mound of the grave, where only pine trees and Chinese parasol trees shelter the cold latch of the gate.

\section{CONCLUSIONS}

According to what is written on the unearthed tombstone, the occupants of the tomb are Yang Gui, the Assistant Magistrate of Fangcheng County of Tangzhou Prefecture and posthumously honored as the Zizhou Prefecture Adjutant during the Tang dynasty, and his wife, née Wang. Yang died in the second year of the Yifeng reign period of Emperor Gaozong (678 CE) in the village of Ninghua in the capital (today's Xi'an City, Shaanxi Province). His was buried in Biyuan (the present site). His wife née Wang died in the first year of the Zhengsheng reign period (695 CE) in the village of Lide in Luozhou (today's Luoyang City, Henan Province). She was temporarily buried in Beimang. Their son buried them together in the ninth year of the Kaiyuan reign period (721 CE). Yang Gui's eldest son, Siji, listed Yang's titles as "Grand Master for Splendid Happiness with Silver Seal and Blue Ribbon, Chamberlain for the Palace Buildings, Upper Pillar of the State, and Dynasty-Founding Baron of the County of Huayin."

The author consulted Old History of the Tang [Jiu Tangshu 旧唐书] and New History of the Tang [Xin Tangshu 新唐书] and discovered a record of a Chamberlain for the Palace Buildings by the surname of Yang, to whom the merit of honest management is accredited. He was active between the eras of Shen- 
long and Kaiyuan. However, it cannot be established whether this person was Yang Gui.

Since this is a secondary burial, the dates of the grave goods ought to be reviewed. During the second year of the era of Yifeng, tri-colored figurines were not yet popular. Tri-colored objects discovered in burials dated to this period comprise only vessels like pan-plates, $y u$-jars and ping-bottles.

The earliest Tang dynasty tomb in the Guanzhong area with a full set of tri-colored figurines is the tomb of $\mathrm{Li} \mathrm{Hui}^{[2]}$ dated to the first year of the Yongchang reign period $(689 \mathrm{CE})$. The glaze on the tri-colored figurines from this tomb is basically monochromatic and not very skillfully applied. Based on the typology of tri-colored figurines, there were no such well-made tri-colored figurines around the time of the second year of the Yifeng reign period. Type $B$ tri-colored male servant figurines from the Yang Gui couple's grave have basically the same form and specifications as the Type I tri-colored male servant figurines from the tomb of Qutu Jizha ${ }^{[3]}$ in Luoyang, which is dated to the second year of the Tianshou reign period under Dowager Empress $\mathrm{Wu}(691 \mathrm{CE})$.

Type A male servant figurines are similar in shape and composition to the green-glazed male servant figurines from the tomb of Xianyu Tinghui, dated to the eleventh year of the Kaiyuan reign pe$\operatorname{riod}(723 \mathrm{CE})$, which is located in the western suburbs of Xi' an. ${ }^{[4]}$ However, the tri-colored noble maid figurines from the tomb of Xianyu Tinghui already have the typical plump features of the Tang dynasty at its prime, whereas the tri-colored maid figurines in the Yang Gui couple's tomb and the mingqi-models [funerary replicas] more closely resemble the objects in the same category discovered in the tomb of Kang Wentong ${ }^{[5]}$ in Xi' an City, which is dated to the first year of the Shengong reign period (697 CE). All things considered, we believe that the tri-colored wares in the tomb of the Yang Gui couple were made during the latter part of the reign of Dowager Empress Wu. Judging by the common application of blue glaze, these were products of a kiln for tricolored wares near Luoyang.

The reason that Lord Yang Gui's wife was buried in Luoyang may be that her son was an official there, and she lived with him in the Village of Lide in Luoyang after she was widowed. In the early years of the Kaiyuan reign period, bestowing official titles became a prevailing practice. Yang Siji, who already occupied a high post (he was originally appointed the Grand Master for Splendid Happiness with Silver Seal and Blue Ribbon), secured a posthumous title for his late father and moved his mother's casket from Luoyang back to Chang' an for burial. Since tricolored burial objects are of high value, it is possible that they were removed prior to the secondary burial. The inscriptions on the epitaph are of exceptional quality, as are the tri-colored objects, suggesting that the funeral was thoughtfully prepared.

The tri-colored wares unearthed from the couple tomb of Yang Gui and his wife are pure white and have a delicate texture. The glaze is bright and thick, the shapes are uniform, and the objects are well made. Among them, the tri-colored ceramic latrine is rare in the Tang dynasty; it provides primary material for the study of Tang tri-colored wares.

Field Crew Chief: Ming Li

Field Crew: Ming Yuan, Ming Li, Jiming Lü and Cunli He

Photography: Minghui Zhang

Reconstruction: Yongjian Zhang and Xiaoli Wang

Drawings: Junxin Liu and Jiming Lü

Prepared by: Ming Li and Ming Yuan 


\section{References Cited}

[1] Shaanxi Provincial Cultural Relics Management Committee 陕西省文物管理委员会. 1959. “Xi'an Yangtouzhen Tang Li Shuang mu de fajue" 西安羊头镇唐李爽墓的发掘 (The Excavation of the Tang Dynasty Tomb of Li Shuang at Yangtouzhen Village, Xi'an City). Wenwu 文物 (Cultural Relics) No. 3.

Xi'an Institute of Archaeology and Relics Preservation 西安市文物保护考古所. 2002. “Tang Yao Wubi mu fajue jianbao" 唐姚无陂墓发掘简报 (The Excavation of the Tang Dynasty Tomb of Yao Wupi). Wenwu 文物 No. 12.

Shaanxi Provincial Institute of Archaeology in Collaboration With the Infrastructural Archaeological Team 陕 西省考古研究所配合基建考古队. 1990. “Xi'an jingshuichang Tang mu qingli jianbao" 西安净水厂唐墓清理 简报 (The Excavation of the Tang Dynasty Tomb at the Water Treatment Plant, Xi'an City). Kaogu yu wenwu 考古与文物 (Archaeology and Cultural Relics) No. 6.

[2] These materials are kept in the Shaanxi Provincial Institute of Archaeology.

[3] The Mengjin Archaeological Team of China National Highway No. 310 国道孟津考古队. 1993. "Luoyang Mengjin Xishantou Tang mu fajue baogao" 洛阳孟津西山头唐墓发掘报告 (The Excavation of the Tang Dynasty Tomb at Xishantou Village, Mengjin County, Luoyang City). Huaxia kaogu华夏考古 (Huaxia Archaeology) No. 1.

[4] Institute of Archaeology, Chinese Academy of Social Sciences中国社会科学院考古研究所. 1980. Tang Chang'an chengjiao Sui Tang mu 唐長安城郊隋唐墓 (Excavation of the Sui and Tang Tombs at Xi'an), Plate 79. Wenwu chubanshe, Beijing.

[5] Xi'an Institute of Archaeology and Relics Preservation 西安市文物保护考古所. 2004. “Tang Kang Wentong mu fajue jianbao" 唐康文通墓发掘简报 (The Excavation of the Tang Dynasty Tomb of Kang Wentong). Wenwu 文物 (Cultural Relics) No. 1.

Wenwu (Cultural Relics) Editor: Ran Wu

Translated by Annie Chan, Ph.D. Visiting Research Scholar, University of Pennsylvania, Philadelphia, PA, United States

This article was originally published as "Xi'an nanjiao Tangdai Yang Gui fufu mu fajue jianbao" 西安南郊唐代杨贵 夫妇墓发掘简报 in Wenwu (Cultural Relics) No. 11, 2016, pp. 20-39. 